\title{
Details Matter: \\ The Impact of Presentation and Information on the Take-up of Financial Incentives for Retirement Saving ${ }^{\text {ti }}$
}

\author{
By EMmanuel SAEZ*
}

\begin{abstract}
We examine the effects of presentation and information on the takeup of financial subsidies for retirement saving in a large randomized experiment carried out with $H \& R$ Block. The subsidies raise take-up and contributions with larger effects when the subsidy is characterized as a matching contribution rather than an equivalent-value tax credit (or cash back), and when filers are informed before the tax season about the subsidy. The results imply that both pure incentives and the presentation of those incentives affect consumer choices. (JEL D14, H24, H31, J26)
\end{abstract}

\begin{abstract}
A growing body of evidence shows that individuals respond not only to the pure economic incentives they face but also to the manner in which such incentives are presented and framed. Such behavior appears to be particularly relevant in analysis of saving choices. Brigitte C. Madrian and Dennis F. Shea (2001), for example, show that changing the default rules for 401(k) enrollment has a significant impact on employee participation rates. Esther Duflo and Saez (2002) show that the behavior of one's colleagues has a significant causal influence on workers' participation in 401(k) plans. Marianne Bertrand et al. (2005) show that changes in the wording of a loan offer have a significant effect on borrowers' choices.

Duflo et al. (2006) used experimental data covering 14,000 tax filers at $60 \mathrm{H} \& \mathrm{R}$ Block tax preparation offices in St. Louis in 2005, and showed that the matching of IRA contributions can significantly raise take-up and contributions. Raising the match rate from $0-20$ percent to 50 percent raised IRA take-up from 3-8 percent to 14 percent. We also showed, using nonexperimental difference-in-difference analysis, that increasing the effective match rate in the federal saver's credit from 25 percent to 100 percent raised take-up by at most 1.3 percentage points 1 Contributions to retirement accounts, conditional on take-up, were also significantly more sensitive to

\footnotetext{
* Department of Economics, University of California, 549 Evans Hall, Berkeley, CA 94720, (e-mail: saez@ econ.berkeley.edu). We gratefully acknowledge the assistance of H\&R Block employees including Mary Beth Granger, Mike Lammers, Scott McBride, Andrew Olson, Paul Peterson, Yvette Ruiz, John Thompson, Jeremy White, and Bernie Wilson, as well as the district and office managers and the 600 tax professionals who implemented the experiment. We thank James Poterba, Joel Slemrod, and two anonymous referees for very helpful comments and discussions. The views expressed are those of the author alone and do not necessarily reflect the views of H\&R Block.

$\dagger$ To comment on this article in the online discussion forum visit the articles page at: http://www.aeaweb.org/articles.php?doi=10.1257/pol.1.1.204

${ }^{1}$ The variation in the federal saver's credit rate comes from differences in income as the credit rate depends (discontinuously) on Adjusted Gross Income (AGI). This variation, however, is not experimental.
} 
variations in effective matching rates in the controlled experiment than in the saver's credit data. We concluded that taxpayers were more responsive to the incentives in our experiment because our subsidy offer was presented transparently, whereas the similar incentives in the federal tax system are difficult to perceive. ${ }^{2}$

All of these findings imply that information and presentation, factors that are often ignored in conventional analysis of public policy, can have first-order effects on individuals' choices and hence on the efficacy of policy interventions, even holding economic incentives constant. Because optimal policy choices hinge sensitively on the size of behavioral responses, and because the presentation and informational details of public policies can often be altered at low cost, a crucial new direction for empirical research is to move beyond merely estimating the size of behavioral responses and instead to analyze how various "details" can shape the size of the behavioral response. It is important to note that some "details" can be altered at low cost (for example the match versus credit framing) while other "details" are most costly to change (such as providing information about a program).

This paper presents new evidence on the importance of presentation and information alternatives in analyzing tax filers' responses to financial incentives for retirement saving contributions. We use data from a large field experiment conducted during the 2006 tax season in collaboration with H\&R Block in St. Louis $\stackrel{3}{3}$ The basic experimental design is simple. H\&R Block customers in St. Louis who filed returns in the same office in 2006 as in 2005 were randomly assigned to a treatment group, which received a 50 percent match on IRA contributions made at the time of filing, or a control group, which received no match. Both groups had account setup fees waived. On top of this basic design, several variations were introduced.

First, a randomly selected subset of treatment group members was presented with a 33 percent credit rebate (cash back) rather than a 50 percent match. While these two subsidies are economically equivalent, previous experiments in the context of charitable giving have shown that a match presentation generates higher take-up than a credit presentation. ${ }^{4}$ This raises important issues because the saver's credit could be restructured to offer matching contributions at relatively low cost.

Second, a different randomly chosen subset of filers received advance notification of the fee waiver (if in the control group) or of the match and the fee waiver (if in the treatment group) via a phone call and letter. Advance notification gives tax filers the chance to plan ahead to take advantage of the match. In addition, because public policies can be advertised and tend to be in place for multiple years, the results with

\footnotetext{
${ }^{2}$ A large number of experimental studies have shown, in the context of charitable contributions, that matching subsidies can increase contributions. Many studies focus on laboratory experiments. See Douglas D. Davis (2006); Davis and Edward L. Millner (2005, 2006); Davis, Millner, and Robert J. Reilly (2005); and Catherine C. Eckel and Philip J. Grossman (2003, 2006b, 2006a,c). There have been fewer field experiment studies. Dean Karlan and John A. List (2007) study the case of contributions to a political interest group. Stephan Meier (2007) studies longitudinal aspects in the context of contributions to a social scholarship fund by students. Eckel and Grossman (2005) analyze the case of Public Radio contributions in Minnesota.

${ }^{3}$ The new experiment expands upon the matching experiments conducted in 2005 and analyzed in Duflo et al. (2006). The new experiment tests how a number of "details" affect IRA contribution decisions.

${ }^{4}$ See Davis (2006); Davis and Millner (2005, 2006); Davis, Millner, and Reilly (2005), and Eckel and Grossman $(2003,2005,2006 a, b, c)$. We discuss below how our findings in the savings case can cast new light on the explanations put forward in the charitable contribution case.
} 
advance notification may be more relevant for predicting the likely effects of a realworld government program.

Third, a random subset of treatment group members was offered the match for regular monthly IRA contributions as well as for contributions made at the time of filing. Recent research on 401(k) plans, where employees make monthly contributions, suggests that employer-provided matching rates raise take-up and contributions (see, for example, Gary V. Engelhardt and Anil Kumar 2004; Gur Huberman, Sheena S. Iyengar, and Wei Jiang 2007). The extent to which those effects are due to pure incentives versus some combination of peer effects, automatic payroll deduction, or other factors is unclear. Testing the sensitivity of IRA take-up to whether monthly contributions are matched can provide evidence on this issue because peer effects and payroll deduction are not applicable to the IRA choice that filers in our experiment faced. Our principal findings can be summarized simply. The matching offer raises take-up and contributions to IRAs. Even after controlling for a variety of taxpayer characteristics, returns filed earlier in the season generally exhibited smaller responses to all of the various subsidies offered than those filed later in the season. The match raised take-up of retirement saving by almost 6 percentage points overall and by more than 10 percentage points for returns filed between March 5 and March 31, 2006. 5

The match offer generated significantly higher take-up and contribution levels than the economically equivalent credit rebate offer. Hence, the form of the subsidy and the presentation of information appear to matter significantly, even when the underlying incentives are identical. Moreover, we can explain why people respond differently to these two different framings. Almost all of this effect occurred because filers made a specific type of suboptimal choice, leaving money on the table.

Advance notification more than doubled IRA take-up rates among filers who were assigned to the match treatment. In sharp contrast, it had no effect on take-up among filers who were not assigned to the match treatment. This suggests there are important interactions between information and incentives. Each can work more effectively in the presence of the other.

The opportunity to receive matches on future monthly IRA contributions had little effect on take-up or contributions. The difference between these results and the positive match effects in 401(k) plans is likely due to differences in the available information and choice context rather than any difference in underlying economic incentives since the match rate in the experiment (50 percent) is also the most common employer matching rate for $401(\mathrm{k})$ plans.

The remainder of the paper is organized as follows. The next two sections describe the experiment and the results of the basic design. The following three sections examine the effects of the three variations on the basic design described above. The final section discusses conclusions and policy implications.

\footnotetext{
${ }^{5}$ The quantitative magnitude of the results is quite robust with respect to the effects of the 2005 experiment analyzed by Duflo et al. (2006), which took place from March 5 to April 5, once the date of filing of the tax return is controlled for.
} 


\section{Background}

The experiment centers around the Express IRA (X-IRA), a product through which H\&R Block offers clients the chance to make IRA contributions at the time of tax preparation. X-IRAs can be funded with the forthcoming tax refund, a personal check, or cash. X-IRAs can be either traditional IRAs, where the contribution is tax deductible and withdrawals are taxed, or Roth IRAs, where contributions are not deductible and qualified withdrawals are untaxed. The minimum annual X-IRA contribution is $\$ 300$ and can be made on a one-time basis or via automatic monthly deductions from a bank account of at least \$25. In the basic experimental design, however, only one-time contributions are matched. There is a $\$ 15$ fee for opening or contributing again to the account at the time of tax preparation (contributions and withdrawals by mail are free) and a $\$ 25$ account termination fee. A $\$ 10$ annual maintenance fee is waived for accounts with balances over $\$ 1,000$ or for those using automatic deductions. Until the balance reaches $\$ 1,000$, the only investment option is an FDIC-insured money market bank account. Take-up of the X-IRA has been modest. In the 2005 tax season, the nationwide X-IRA take-up rate (including opening and additional contributions) was approximately 1.3 percent.

The experiment was conducted in $60 \mathrm{H} \& \mathrm{R}$ Block offices in St. Louis between January 20 and March 31, 2006. Any client coming to prepare taxes at one of the relevant offices, who had also prepared their taxes at the same office in 2005, received a waiver of the \$15 X-IRA setup fee and was randomly assigned to either the control group, which received no match, or the treatment group, which received a 50 percent match on X-IRA contributions up to $\$ 1,000[$ Because IRAs are individually owned, the same offer was extended to each spouse in married couples filing jointly.

\section{A. Experimental Groups}

To explore variations on the basic design, the 60 offices were divided into 3 groups ${ }^{7}$ The experimental design is laid out in Table 1 . As shown in panel A, the match versus credit presentation was implemented in 19 offices. In these offices, 80 percent of filers were in the control group. Ten percent were offered the 50 percent match, and 10 percent were offered a 33 percent credit rebate on X-IRA contributions. Randomization occurred at the customer level based on the last two digits of the primary taxpayer's Social Security Number (SSN). As we discuss below in detail, absent any credit constraints or other frictions, the credit generates exactly the same budget set as the match, since a credit at rate $t$ is equivalent to a match at rate $t /(1-t)$. To see this, suppose an individual is offered the 50 percent match and chooses to contribute $\$ 400$ and hence obtains a \$200 match and a total X-IRA

\footnotetext{
${ }^{6}$ We restricted eligibility to prior year customers to protect the external validity of our findings. In particular, we wanted to avoid the possibility that our sample would contain too many people with a higher than average propensity to save via selection into the sample of people who somehow learned about the matching offer and came to H\&R Block specifically to receive the match.

${ }^{7} \mathrm{H} \& \mathrm{R}$ Block offices are grouped into districts of roughly 12 offices each. Because training and management occur at the district level, it was necessary to keep districts intact when dividing the offices into the three groups. We chose the office grouping to balance the income and racial distribution of customers subject to the constraint that we keep districts intact.
} 
TABLE 1-EXPERIMENT LAY-OUt

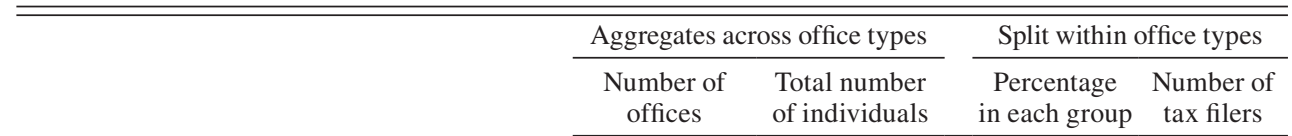

(1)

Panel A: Match versus credit presentation

50 percent match presentation

33 percent credit presentation

Control (no match or credit offered)
19
(2)

(3)

15,852
Panel B: Advance notification
(4)

50 percent match offered with advance notification 50 percent match offered without advance notification

No match with advance notification

No match without advance notification

$\begin{array}{ll}10 & 1,561 \\ 10 & 1,588 \\ 80 & 12,703\end{array}$

Panel C: Match for monthly contributions

50 percent match offered

Control (no match offered)
20

17,578

\begin{tabular}{lll}
\hline Panel D: Grand total across office types & 60 & 48,308
\end{tabular}

Match or credit offered

No match or credit offered

$21 \quad 14,878$

$\begin{array}{ll}10.4 & 1,831 \\ 24.1 & 4,232 \\ 10.2 & 1,796 \\ 55.3 & 9,719\end{array}$

Notes: Panels A, B, and C lay out the experimental groups in each of the three sets of offices. Within each set of offices, tax filers were randomized into treatment and control groups based on last two digits of Social Security numbers. In the match versus credit presentation group (panel A), tax filers in the treatment groups were offered either a 50 percent match or an economically equivalent 33 percent credit rebate. In the advance notification group (panel B), tax filers in the treatment group were offered a match. In both treatment and control groups, a subset of tax filers was scheduled to receive a phone call notifying them of the IRA opportunity and describing the match in the case of the treatment group. Tax filers were also randomized into the advance notification versus no advance notification groups. In the Match for Monthly Contributions group (panel C), the treatment group was offered a 50 percent match for a one-time contribution and also a 50 precent match on monthly contributions (if the tax filer decided to start such monthly contributions).

contribution of $\$ 600$. Under the credit scenario, this allocation can be replicated by making a $\$ 600$ contribution and receiving a 33 percent rebate of $\$ 200$ so that the net out-of-pocket cost is $\$ 400$, as in the match scenario. Conversely, any allocation chosen under the credit scenario can be replicated under the match scenario. Because the match was offered for contributions of $\$ 300$ to $\$ 1,000, \frac{8}{7}$ the rebate was offered for contributions of $\$ 450$ to $\$ 1,500$, which generate out-of-pocket costs between $\$ 300$ and $\$ 1,000$. Notably, those who were offered the credit could make X-IRA contributions between $\$ 300$ and $\$ 450$, but such contribution choices did not receive the credit and would be strictly dominated by making a $\$ 450$ contribution coupled with a $\$ 150$ rebate. The rebate was provided in the form of a check mailed to the tax filers within two weeks of tax filing. 9 Therefore, a key difference between the match and the rebate is that the rebate required tax filers to advance the match money until

\footnotetext{
${ }^{8}$ Contributions above $\$ 1,000$ received a total match of $\$ 500$ so that the match was effectively capped at $\$ 500$. H\&R Block requires minimum contributions of at least $\$ 300$.

${ }^{9}$ The matching funds were deposited to the X-IRA account at the end of the tax season in mid-April.
} 
they received the rebate check within two weeks. This can be costly if tax filers are severely credit constrained. Most tax filers receive substantial tax refunds which can be used to make X-IRA contributions and might mitigate credit constraints in our specific setup. The rebate can also be more costly than the match if tax filers face large transaction costs of cashing the rebate check, the risk of losing the check (or getting it stolen in the mail) or would be required to share the proceeds of a mailed check with household members. Obviously, credit constraints or the friction costs just described break the equivalence between the match and the credit.

As shown on panel B of Table 1, advance notification was implemented in 20 offices. In these offices, about 20 percent of randomly selected 2005 filers, divided equally between matched and control groups, were scheduled to be called in November 2005. Those who were reached were informed that, if they returned to the same office in 2006, they would receive a waiver of X-IRA setup fees. Treatment group members were also informed of the 50 percent match. A marketing company that routinely works with H\&R Block attempted up to three calls, if necessary, to reach each filer. Filers who were reached by phone also received a mailing in late December 2005 explaining the offer again. The remaining 80 percent of 2005 filers in those offices were not scheduled to be called. Among those, 30 percent received a match.

As shown in panel $\mathrm{C}$, matching of monthly contributions was provided in the remaining 21 offices. In those offices, 89 percent of 2005 filers were in the control group and the remaining 11 percent received the 50 percent match offer described above. In addition, unlike other groups, treatment group members in these offices could also receive the match (between \$25 and \$100) for systematic monthly contributions from a bank account through the end of 2006. Once initiated, contributions would continue at the same rate unless the filer actively chose to change the level. This subexperiment was designed to test the theory that people find it easier to commit to forego future consumption in order to build up savings than to give up immediate consumption 10

\section{B. Implementation}

The steps taken to implement the experiment were very similar to those described in Duflo et al. (2006). Briefly, to prompt the information required for the tax return, the software used by tax professionals at H\&R Block displays a series of screens in a default sequence including a screen for X-IRA participation. Tax professionals can override the default sequence, however, and skip or return to any screen at any time. In the experiment, when the X-IRA screen was activated, a special popup window automatically appeared describing the offer corresponding to the client's treatment status. Tax professionals then informed clients that they were receiving a special X-IRA offer as part of a research project and that they were under no obligation to participate. The professionals also provided H\&R Block's standard X-IRA (2004).

${ }^{10}$ A similar hypothesis underlies the "Save More Tomorrow" research of Richard Thaler and Shlomo Benartzi 
explanation that IRAs are not for everyone and that there can be penalties for early withdrawal.

Although random assignment was based on the last two digits of the social security number of the primary filer, tax professionals were not informed of the algorithm, and a client's treatment status was not revealed by the software, until after reaching the X-IRA offer screen. Thus, tax professionals' decisions to offer (or skip) the X-IRA screen were independent of treatment status. The decision may, however, have depended on an assessment of whether the client was likely to make a contribution. We analyze take-up and contributions for all tax filers by treatment status regardless of whether they received an offer (i.e., we present "intent-to-treat" estimates).

The experiment ran from January 20 to March 31, 2006. With the exception of the advance notification calls and letters described above, the experiment was not advertised in advance ${ }^{11}$ However, some clients may have anticipated the offers since we had run a similar experiment in the same offices during the last month of the 2005 tax season. H\&R Block made the matching payments totalling approximately $\$ 333,000$.

\section{Data and Descriptive Statistics}

The analysis is based on data that include information from 2005 and 2006 tax returns, information on X-IRA contributions, and other information collected by H\&R Block during tax preparation. We exclude filers with earnings below $\$ 300$ from the analysis, since they were not eligible to make X-IRA contributions. We prepared statistical programs and sent them to H\&R Block, which then sent us back the output of those programs. The output of the programs contains only statistical compilations and no individual information. The tables and figures reported in this paper are created using this statistical output.

Table 2 shows descriptive statistics for the treatment and control groups in the three sets of offices. Within each office type, none of the differences between the treatment and control groups are significant at the 5 percent level, which suggests that the randomization was successful. About 13 percent of the 2006 sample also participated in the 2005 experiment (the 2005 experiment ran from March 5 to April 5). The average AGI of $\$ 34,000$ to $\$ 40,000$ is lower than the national average of about $\$ 50,000$ (and lower that of the sample in the 2005 experiment because early filers tend to have lower incomes). About half of the sample owns a home. At least 85 percent received a federal refund larger than $\$ 500$, which would generally allow them to fund a $\$ 300 \mathrm{X}$-IRA out of their refund even if they owed taxes at the state level. The average tax refund is around $\$ 2,800$. Less than 30 percent of the sample has positive investment income. About 40 percent of filers in the sample receive the EITC. Filers

\footnotetext{
${ }^{11}$ Pretax season training sessions were conducted by an H\&R Block implementation manager. Tax professionals are paid $\$ 5.50$ for each X-IRA account opened or contributed to by their clients and this commission structure was in place for our experiment. More generally, tax professionals receive greater compensation for completing more complicated (and therefore more time consuming) returns. Duflo et al. (2006) show that tax professionals differ substantially in the extent to which their clients sign up for X-IRAs even after controlling for client characteristics and office.
} 
TABle 2-Descriptive Statistics

\begin{tabular}{|c|c|c|c|c|c|c|c|c|c|c|c|}
\hline & \multicolumn{5}{|c|}{ Match versus credit presentation } & \multicolumn{3}{|c|}{ Advance notification } & \multicolumn{3}{|c|}{$\begin{array}{c}\text { Match monthly } \\
\text { contributions }\end{array}$} \\
\hline & $\begin{array}{l}50 \% \\
\text { match }\end{array}$ & $\begin{array}{l}33 \% \\
\text { credit }\end{array}$ & Control & $\begin{array}{l}\text { Match } \\
\text { versus } \\
\text { credit }\end{array}$ & $\begin{array}{l}\text { Credit } \\
\text { versus } \\
\text { control } \\
\end{array}$ & $\begin{array}{l}50 \% \\
\text { match }\end{array}$ & $\begin{array}{c}\text { No } \\
\text { match }\end{array}$ & Difference & $\begin{array}{l}50 \% \\
\text { match }\end{array}$ & $\begin{array}{c}\text { No } \\
\text { match }\end{array}$ & Difference \\
\hline & (1) & (2) & (3) & (4) & (5) & (6) & (7) & (8) & (9) & (10) & (11) \\
\hline $\begin{array}{l}\text { Was in St. Louis } 2005 \\
\text { experiment }\end{array}$ & $\begin{array}{c}0.13 \\
(0.009)\end{array}$ & $\begin{array}{c}0.14 \\
(0.009)\end{array}$ & $\begin{array}{c}0.124 \\
(0.003)\end{array}$ & $\begin{array}{l}-0.01 \\
(0.012)\end{array}$ & $\begin{array}{c}0.02 \\
(0.009)\end{array}$ & $\begin{array}{c}0.14 \\
(0.004)\end{array}$ & $\begin{array}{c}0.13 \\
(0.003)\end{array}$ & $\begin{array}{c}0.006 \\
(0.005)\end{array}$ & $\begin{array}{c}0.13 \\
(0.008)\end{array}$ & $\begin{array}{c}0.13 \\
(0.003)\end{array}$ & $\begin{array}{c}0.004 \\
(0.009)\end{array}$ \\
\hline Adjusted gross income & $\begin{array}{c}34,109 \\
(714)\end{array}$ & $\begin{array}{c}34,150 \\
(767)\end{array}$ & $\begin{array}{c}33,804 \\
(252)\end{array}$ & $\begin{array}{c}-41 \\
(1048)\end{array}$ & $\begin{array}{c}346 \\
(761)\end{array}$ & $\begin{array}{c}39,527 \\
(518)\end{array}$ & $\begin{array}{l}39,235 \\
(329)\end{array}$ & $\begin{array}{c}292 \\
(589)\end{array}$ & $\begin{array}{c}38,929 \\
(883)\end{array}$ & $\begin{array}{c}37,654 \\
(269)\end{array}$ & $\begin{array}{l}1,275 \\
(828)\end{array}$ \\
\hline $\begin{array}{l}\text { Adjusted gross income, } \\
\text { married filling jointly }\end{array}$ & $\begin{array}{l}58,676 \\
(1,856)\end{array}$ & $\begin{array}{l}58,953 \\
(2,338)\end{array}$ & $\begin{array}{l}57,908 \\
(675)\end{array}$ & $\begin{array}{c}-277 \\
(2,971)\end{array}$ & $\begin{array}{c}1,045 \\
(2,087)\end{array}$ & $\begin{array}{l}63,237 \\
(1,231)\end{array}$ & $\begin{array}{c}62,382 \\
(632)\end{array}$ & $\begin{array}{c}855 \\
(1,248)\end{array}$ & $\begin{array}{l}66,630 \\
(2,089)\end{array}$ & $\begin{array}{l}63,757 \\
(590)\end{array}$ & $\begin{array}{l}2,873 \\
(1821)\end{array}$ \\
\hline $\begin{array}{l}\text { Adjusted gross income } \\
\text { non married }\end{array}$ & $\begin{array}{c}25,872 \\
(540)\end{array}$ & $\begin{array}{l}26,482 \\
(530)\end{array}$ & $\begin{array}{c}26,270 \\
(200)\end{array}$ & $\begin{array}{l}-611 \\
(756)\end{array}$ & $\begin{array}{c}213 \\
(594)\end{array}$ & $\begin{array}{c}27,909 \\
(360)\end{array}$ & $\begin{array}{c}27,776 \\
(304)\end{array}$ & $\begin{array}{c}133 \\
(494)\end{array}$ & $\begin{array}{c}26,885 \\
(596)\end{array}$ & $\begin{array}{l}26771 \\
(203)\end{array}$ & $\begin{array}{c}114 \\
(621)\end{array}$ \\
\hline Fraction married & $\begin{array}{c}0.25 \\
(0.011)\end{array}$ & $\begin{array}{c}0.24 \\
(0.011)\end{array}$ & $\begin{array}{c}0.238 \\
(0.004)\end{array}$ & $\begin{array}{c}0.01 \\
(0.015)\end{array}$ & $\begin{array}{l}-0.00 \\
(0.011)\end{array}$ & $\begin{array}{c}0.33 \\
(0.006)\end{array}$ & $\begin{array}{c}0.33 \\
(0.004)\end{array}$ & $\begin{array}{l}-0.002 \\
(0.007)\end{array}$ & $\begin{array}{c}0.30 \\
(0.011)\end{array}$ & $\begin{array}{c}0.29 \\
(0.004)\end{array}$ & $\begin{array}{c}0.009 \\
(0.012)\end{array}$ \\
\hline Overpayment amount & $\begin{array}{c}2,874 \\
(51)\end{array}$ & $\begin{array}{c}2,762 \\
(50)\end{array}$ & $\begin{array}{c}2,832 \\
(18)\end{array}$ & $\begin{array}{l}112 \\
(72)\end{array}$ & $\begin{array}{l}-70 \\
(54)\end{array}$ & $\begin{array}{c}2,764 \\
(27)\end{array}$ & $\begin{array}{c}2,726 \\
(20)\end{array}$ & $\begin{array}{c}38 \\
(33)\end{array}$ & $\begin{array}{c}2,796 \\
(52)\end{array}$ & $\begin{array}{c}2,761 \\
(18)\end{array}$ & $\begin{array}{l}35 \\
(54)\end{array}$ \\
\hline $\begin{array}{l}\text { Fraction with over- } \\
\quad \text { payment }>500\end{array}$ & $\begin{array}{c}0.89 \\
(0.008)\end{array}$ & $\begin{array}{c}0.86 \\
(0.009)\end{array}$ & $\begin{array}{c}0.879 \\
(0.003)\end{array}$ & $\begin{array}{c}0.02 \\
(0.012)\end{array}$ & $\begin{array}{l}-0.02 \\
(0.009)\end{array}$ & $\begin{array}{c}0.87 \\
(0.004)\end{array}$ & $\begin{array}{c}0.87 \\
(0.003)\end{array}$ & $\begin{array}{c}0.005 \\
(0.005)\end{array}$ & $\begin{array}{c}0.85 \\
(0.009)\end{array}$ & $\begin{array}{c}0.87 \\
(0.003)\end{array}$ & $\begin{array}{l}-0.015 \\
(0.009)\end{array}$ \\
\hline $\begin{array}{l}\text { Fraction with positive } \\
\text { investment income }\end{array}$ & $\begin{array}{c}0.23 \\
(0.011)\end{array}$ & $\begin{array}{c}0.26 \\
(0.011)\end{array}$ & $\begin{array}{c}0.238 \\
(0.004)\end{array}$ & $\begin{array}{l}-0.02 \\
(0.015)\end{array}$ & $\begin{array}{c}0.02 \\
(0.011)\end{array}$ & $\begin{array}{c}0.29 \\
(0.006)\end{array}$ & $\begin{array}{c}0.29 \\
(0.004)\end{array}$ & $\begin{array}{c}0.000 \\
(0.007)\end{array}$ & $\begin{array}{c}0.27 \\
(0.011)\end{array}$ & $\begin{array}{c}0.27 \\
(0.004)\end{array}$ & $\begin{array}{l}-0.002 \\
(0.012)\end{array}$ \\
\hline Fraction home owner & $\begin{array}{c}0.47 \\
(0.013)\end{array}$ & $\begin{array}{c}0.45 \\
(0.012)\end{array}$ & $\begin{array}{c}0.462 \\
(0.004)\end{array}$ & $\begin{array}{c}0.02 \\
(0.018)\end{array}$ & $\begin{array}{l}-0.01 \\
(0.013)\end{array}$ & $\begin{array}{c}0.51 \\
(0.006)\end{array}$ & $\begin{array}{c}0.51 \\
(0.005)\end{array}$ & $\begin{array}{c}0.002 \\
(0.008)\end{array}$ & $\begin{array}{c}0.52 \\
(0.012)\end{array}$ & $\begin{array}{c}0.50 \\
(0.004)\end{array}$ & $\begin{array}{c}0.016 \\
(0.013)\end{array}$ \\
\hline $\begin{array}{l}\text { Fraction EITC } \\
\text { recipients }\end{array}$ & $\begin{array}{c}0.44 \\
(0.013)\end{array}$ & $\begin{array}{c}0.45 \\
(0.012)\end{array}$ & $\begin{array}{c}0.448 \\
(0.004)\end{array}$ & $\begin{array}{l}-0.00 \\
(0.018)\end{array}$ & $\begin{array}{l}-0.00 \\
(0.013)\end{array}$ & $\begin{array}{c}0.38 \\
(0.006)\end{array}$ & $\begin{array}{c}0.36 \\
(0.004)\end{array}$ & $\begin{array}{c}0.013 \\
(0.008)\end{array}$ & $\begin{array}{c}0.39 \\
(0.012)\end{array}$ & $\begin{array}{c}0.40 \\
(0.004)\end{array}$ & $\begin{array}{l}-0.006 \\
(0.013)\end{array}$ \\
\hline Observations & 1,561 & 1,588 & 12,703 & & & 6,063 & 11,515 & & 1,617 & 13,261 & \\
\hline
\end{tabular}

Notes: This table presents the covariates across treated and control groups for the three groups of offices. Standard errors in parentheses below the coefficients.

in the match versus credit group have somewhat lower income and home ownership rates and are more likely to be single and receive the EITC. There are about 15,000 tax return observations in each of the three groups. Out of the roughly 48,300 experimental tax filers, about 10,800 received a match (or credit) offer. Appendix Table A1 reports X-IRA participation and contributions by office type.

\section{Interaction with 2005 Experiment}

The 2005 experiment took place between March 5 and April 5 in the same offices. Filers were randomized into a control group, a 20 percent match group, and a 50 percent match group. The 2006 sample consisted of all of those filers and all other 2006 filers in the 60 St. Louis offices, but in each case the filer was only included if the return was filed in the same office in both years. As a result, some 2006 filers were in the 2005 experiment and some were not. The working paper version of this study (Saez 2007) analyzes the interactions between the two experiments and finds modest interactions. As a result, controlling for those interactions has a minimal effect on our results. Two points should be noted. First, relative to filers who did 
not participate in the 2005 experiment, those who participated in 2005 are no more likely to return to the same office in 2006 , and they are only very slightly more likely to take up the match in 2006. Second, relative to filers in the control group in 2005, those who received a match offer in 2005 are only slightly more likely to contribute to an IRA in 2006 suggesting that dynamic effects are modest in the X-IRA environment of this experiment 12

\section{Effects of the Match}

Table 3 presents the effects of the basic match experiment. That is, the effects of the "pure" 50 percent match with no advance notification. The table combines data from all three groups of offices, but excludes customers who were called in advance or who received a "credit" offer ${ }^{13}$ The average take-up of the X-IRA was 3.07 percent in the control group and 8.91 percent in the 50 percent match group. The raw difference is 5.84 percentage points and is highly significant. The difference is almost the same, 5.72 percentage points after controlling for all of the variables listed in Table 2 (to control for residual differences between the groups), office-group dummies (to control for the likelihood of being matched), and a dummy for whether the person would have been matched in 2005 (to control for the correlation between match rules in 2005 and 2006) ${ }^{14}$ Measured at the tax return level, the effects are larger among married couples ( 8.78 percentage points) than singles ( 4.48 percentage points) ${ }^{15}$

Table 4 explores the heterogeneity in take-up and contribution levels by characteristics in a regression framework, showing the OLS regression coefficients of an X-IRA outcome (take-up in columns 1 and 2, contributions in columns 3 and 4) on a variety of explanatory factors. Table 4 shows that being married or owning a home increases the effects of the match on take-up significantly. In contrast, being single, having dependents, or obtaining a refund in excess of $\$ 500$ increases take-up without the match. Having higher overall income or investment income raises take-up regardless of match status.

The effects we find in Table 3 are substantially smaller than the effects in the 2005 matching experiment (Duflo et al. 2006), where the difference in X-IRA take-up between the 50 percent match group and the control group was 11.07 percentage points for the whole sample, 15.42 percentage points for married couples, and 8.69 percentage points for singles (Duflo et al. 2006). It turns out that the difference can be primarily attributed to the differences in take-up rates by filing date. Among

\footnotetext{
${ }^{12}$ This stands in contrast to findings in the context of 401(k), where inducing individuals to start contributing through a change in default rules (Madrian and Shea 2001) or through committing future pay raises (Thaler and Benartzi 2004) has very strong dynamic effects.

${ }^{13}$ The table does include data from the offices where systematic monthly contributions were eligible to be matched. The net increase in X-IRA take-up due to that option, however, was quite low, as described below, and so has a very small effect on the overall test of the "pure" 50 percent matching incentive.

${ }^{14}$ Controlling for 2005 assignment status allows us to interpret our impact estimates as the impact of receiving the treatment in 2006 conditional on not receiving a treatment in 2005.

${ }^{15}$ If the saving choices of the two spouses in a married couple were independent it would not be surprising to find twice the effect among married couples as among singles. Because we believe the saving decisions of spouses are highly correlated, we think return-level comparisons (rather than per capita comparison) are more interesting.
} 


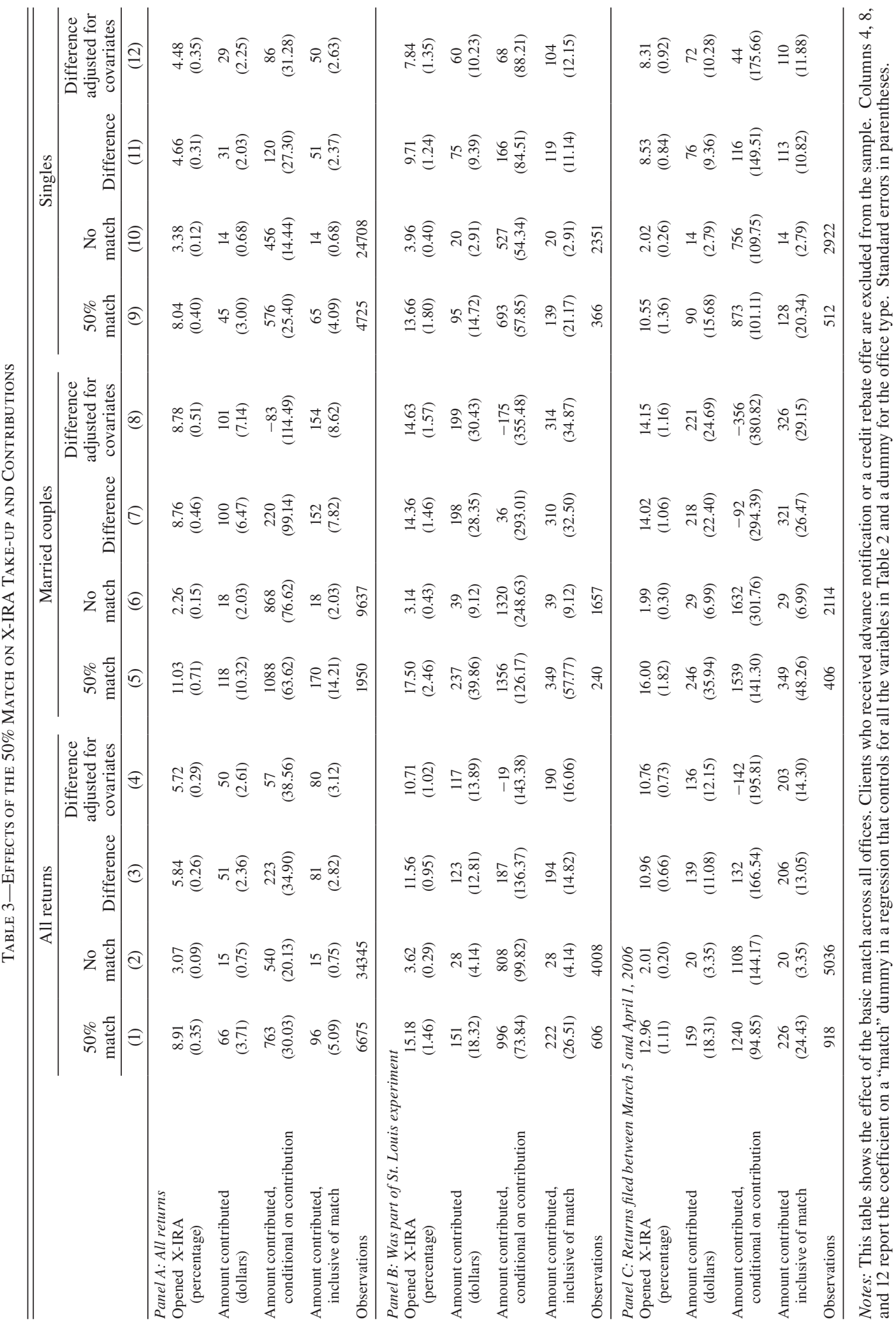


TABle 4-Effects of the 50\% Match by Individual Characteristics

\begin{tabular}{|c|c|c|c|c|}
\hline & \multicolumn{2}{|c|}{ X-IRA take-up (percentage) } & \multicolumn{2}{|c|}{$\begin{array}{l}\text { Amount contributed } \\
\text { (unconditional, dollars) }\end{array}$} \\
\hline & Effect & Effect $\times$ match 2006 & Effect & Effect $\times$ match 2006 \\
\hline & (1) & (2) & (3) & (4) \\
\hline Married & $\begin{array}{l}-1.05 \\
(0.27)\end{array}$ & $\begin{array}{l}2.61 \\
(0.66)\end{array}$ & $\begin{array}{l}0.85 \\
(2.42)\end{array}$ & $\begin{array}{l}47.98 \\
(5.90)\end{array}$ \\
\hline Quartile 2 & $\begin{array}{l}1.57 \\
(0.34)\end{array}$ & $\begin{array}{l}1.79 \\
(0.83)\end{array}$ & $\begin{array}{c}6.08 \\
(3.02)\end{array}$ & $\begin{array}{l}12.25 \\
(7.44)\end{array}$ \\
\hline Quartile 3 & $\begin{array}{c}1.80 \\
(0.33)\end{array}$ & $\begin{array}{c}0.82 \\
(0.82)\end{array}$ & $\begin{array}{l}7.32 \\
(2.98)\end{array}$ & $\begin{array}{c}6.93 \\
(7.37)\end{array}$ \\
\hline Quartile 4 & $\begin{array}{c}0.81 \\
(0.35)\end{array}$ & $\begin{array}{c}2.42 \\
(0.87)\end{array}$ & $\begin{array}{c}4.33 \\
(3.16)\end{array}$ & $\begin{array}{l}34.64 \\
(7.87)\end{array}$ \\
\hline Has investment income & $\begin{array}{c}0.65 \\
(0.28)\end{array}$ & $\begin{array}{c}3.12 \\
(0.69)\end{array}$ & $\begin{array}{l}12.22 \\
(2.49)\end{array}$ & $\begin{array}{l}61.75 \\
(6.17)\end{array}$ \\
\hline Own a home & $\begin{array}{l}-0.27 \\
(0.25)\end{array}$ & $\begin{array}{l}2.05 \\
(0.62)\end{array}$ & $\begin{array}{l}-0.11 \\
(2.25)\end{array}$ & $\begin{array}{l}17.35 \\
(5.55)\end{array}$ \\
\hline Overpayment $>500$ & $\begin{array}{c}1.78 \\
(0.34)\end{array}$ & $\begin{array}{c}1.52 \\
(0.86)\end{array}$ & $\begin{array}{l}11.69 \\
(3.05)\end{array}$ & $\begin{array}{l}-20.94 \\
(7.75)\end{array}$ \\
\hline Has dependent & $\begin{array}{l}1.47 \\
(0.23)\end{array}$ & $\begin{array}{c}0.11 \\
(0.58)\end{array}$ & $\begin{array}{c}3.22 \\
(2.10)\end{array}$ & $\begin{array}{c}8.52 \\
(5.22)\end{array}$ \\
\hline Observations & 41,004 & & 41,004 & \\
\hline
\end{tabular}

Notes: Coefficients of the regression of each characteristic (columns 1 and 3) and each characteristic interacted with the match (columns 2 and 4). Standard errors in parentheses.

customers who filed between March 5 and April 1, 2006 (the time period of the 2005 experiment of Duflo et al. 2006 was March 5 to April 5), the increase in take-up due to the match is 10.76 percentage points for the whole sample, 14.15 for married couples, and 8.31 for singles as shown in the lowest panel of Table 3. These figures are not significantly different from the 2005 estimates noted above.

The basic 2006 experiment therefore shows that the effect of the match is stable from year to year but differs appreciably across filing dates ${ }^{16}$ To explore this issue further, Figure 2 plots the coefficients of a regression of an X-IRA contribution dummy on filing time decile dummies interacted with the match treatment dummies (and including also uninteracted filing time dummies in the regression). The bold graph shows that filing a return at a later date, without controlling for any additional variables, increases take-up very significantly when a match is offered (from between 2 and 5.5 percentage points at early filing dates to more than 10 points among later filing dates). The dashed graph displays the filing date effects but now

\footnotetext{
${ }^{16}$ It is possible that the apparent stability of results reflects offsetting differences between the 2006 and 2005 experiments. For example, tax professionals were likely to be more comfortable offering the match in 2006 because they had experienced it in 2005. This should have raised client take-up. On the other hand, the training and mid-experiment monitoring and encouragement of tax professionals appeared to us to be less intense in 2006 than in 2005. Regardless of the factors resulting in the stability of the late season results, we believe the within-season differences are real.
} 
controlling for all the variables introduced in Table 4! ${ }^{17}$ Interestingly and perhaps surprisingly, the matching effects of the filing dates are only about one third lower than without controls. This shows that differences in the income or other observed characteristics of tax filers cannot explain more than a third of the effects of the match by filing date. One plausible explanation is that early filers are more impatient than later filers, even controlling for observable characteristics. After all, by filing earlier they receive their tax refunds earlier. If so, this might be a signal for needing the tax refund money urgently. For example, tax filers who are credit constrained and impatient to buy a large consumption item or tax filers who are indebted and face very high costs of credit would be more impatient to get their refund than tax filers with buffer stock savings. As a result, it is understandable that those constrained and impatient tax filers would be less willing to consider reducing their refund to contribute to an X-IRA $\stackrel{18}{18}$ It should be noted that our crude control dummy variable for refund size may not fully control for differences in the size of refunds across filing dates. As a result, some of the residual difference in match take-up behavior might still be due to differences in refund sizes across filing dates rather than differences in preferences.

\section{Match versus Credit Presentation}

Several lab and field experiments show that matching offers tend to generate more charitable giving than economically equivalent rebates or cash back (see footnote 1). Duflo et al. (2006) provide evidence consistent with those findings but in the context of retirement saving. They show that variations in effective match rates generate larger responses in a matching experiment than in the existing federal saver's credit. This difference could be due to the difference in taxpayer responses to a match versus a credit, or to a variety of other differences between how the experimental match offer and the federal saver's credit are implemented and perceived. In this section, we present the first experimental evidence on the effects of match versus credit presentations on the take-up of, and contributions to, retirement savings accounts.

Table 5 shows results for the offices where the match and credit options were presented. Both groups have higher take-up rates than the control group. The more interesting comparisons are between the match and credit groups. Relative to the credit group, the match group has a higher take-up rate by 3.68 percentage points; among those who participate, match group members averaged $\$ 153$ more in contributions (inclusive of match, thus measuring the amount going into the IRA). Both of these effects are statistically different from zero. The results imply that taxpayers do not perceive the match and the credit to be economically identical, even though they are for unconstrained individuals as we previously explained. As with the general take-up of the match shown in Figure 1, take-up of the credit and the difference

\footnotetext{
17 The control variables are included directly and interacted with the match as in Table 4.

${ }^{18}$ An alternative explanation, which is not inconsistent with the first, is that tax professionals become more competent at explaining the offer as they gain experience with the experiment over the course of the tax season. Tax professionals also become less busy after the February peak filing period has past. Unfortunately, because tax professional experience and filing timing are closely correlated, our data do not allow us to separate those two hypotheses.
} 
Table 5-Effect of Presentation: Match versus Credit

\begin{tabular}{|c|c|c|c|c|c|c|c|c|c|}
\hline & \multicolumn{3}{|c|}{ Means } & \multicolumn{3}{|c|}{ Differences } & \multicolumn{3}{|c|}{$\begin{array}{l}\text { Differences adjusted for } \\
\text { covariates }\end{array}$} \\
\hline & $\begin{array}{l}\text { Match } \\
\text { group }\end{array}$ & $\begin{array}{l}\text { Credit } \\
\text { group }\end{array}$ & $\begin{array}{l}\text { Control } \\
\text { group }\end{array}$ & $\begin{array}{l}\text { Match } \\
\text { versus } \\
\text { control }\end{array}$ & $\begin{array}{l}\text { Match } \\
\text { versus } \\
\text { credit }\end{array}$ & $\begin{array}{l}\text { Credit } \\
\text { versus } \\
\text { control }\end{array}$ & $\begin{array}{l}\text { Match } \\
\text { versus } \\
\text { control }\end{array}$ & $\begin{array}{l}\text { Match } \\
\text { versus } \\
\text { credit }\end{array}$ & $\begin{array}{l}\text { Credit } \\
\text { versus } \\
\text { control }\end{array}$ \\
\hline & (1) & (2) & (3) & (4) & (5) & (6) & (7) & (8) & (9) \\
\hline \multicolumn{10}{|l|}{ Panel A: All filers } \\
\hline $\begin{array}{l}\text { Fraction open an X-IRA } \\
\text { (percentage) }\end{array}$ & $\begin{array}{l}10.19 \\
(0.77)\end{array}$ & $\begin{array}{c}6.42 \\
(0.62)\end{array}$ & $\begin{array}{c}3.34 \\
(0.16)\end{array}$ & $\begin{array}{c}6.85 \\
(0.53)\end{array}$ & $\begin{array}{c}3.76 \\
(0.98)\end{array}$ & $\begin{array}{c}3.09 \\
(0.50)\end{array}$ & $\begin{array}{c}6.11 \\
(0.64)\end{array}$ & $\begin{array}{l}3.68 \\
(0.97)\end{array}$ & $\begin{array}{l}2.40 \\
(0.61)\end{array}$ \\
\hline $\begin{array}{l}\text { Amount contributed } \\
\text { (unconditional, dollars) }\end{array}$ & $\begin{array}{l}56.14 \\
(5.86)\end{array}$ & $\begin{array}{l}41.47 \\
(5.61)\end{array}$ & $\begin{array}{r}13.55 \\
(0.89)\end{array}$ & $\begin{array}{l}42.59 \\
(3.26)\end{array}$ & $\begin{array}{l}14.67 \\
(8.11)\end{array}$ & $\begin{array}{l}27.92 \\
(3.20)\end{array}$ & $\begin{array}{l}34.28 \\
(3.97)\end{array}$ & $\begin{array}{l}14.51 \\
(8.05)\end{array}$ & $\begin{array}{l}19.85 \\
(3.91)\end{array}$ \\
\hline $\begin{array}{l}\text { Amount contributed } \\
\text { (inclusive of match, unconditional) }\end{array}$ & $\begin{array}{c}82.5 \\
(8.20)\end{array}$ & $\begin{array}{l}41.5 \\
(5.61)\end{array}$ & $\begin{array}{c}13.6 \\
(0.89)\end{array}$ & $\begin{array}{c}68.9 \\
(3.83)\end{array}$ & $\begin{array}{l}41.0 \\
(9.90)\end{array}$ & $\begin{array}{c}27.9 \\
(3.20)\end{array}$ & $\begin{array}{c}60.6 \\
(4.67)\end{array}$ & $\begin{array}{l}40.9 \\
(9.83)\end{array}$ & $\begin{array}{c}19.8 \\
(3.91)\end{array}$ \\
\hline $\begin{array}{l}\text { Amount contributed } \\
\text { (conditional) }\end{array}$ & $\begin{array}{l}558 \\
(40)\end{array}$ & $\begin{array}{l}672 \\
(63)\end{array}$ & $\begin{array}{l}439 \\
(19)\end{array}$ & $\begin{array}{l}119 \\
(39)\end{array}$ & $\begin{array}{l}-114 \\
(71)\end{array}$ & $\begin{array}{l}233 \\
(49)\end{array}$ & $\begin{array}{l}-10 \\
(48)\end{array}$ & $\begin{array}{l}-109 \\
(61)\end{array}$ & $\begin{array}{l}83 \\
(54)\end{array}$ \\
\hline $\begin{array}{l}\text { Amount contributed } \\
\text { (conditional, inclusive of match) }\end{array}$ & $\begin{array}{l}820 \\
(53)\end{array}$ & $\begin{array}{l}672 \\
(63)\end{array}$ & $\begin{array}{l}439 \\
(19)\end{array}$ & $\begin{array}{l}381 \\
(45)\end{array}$ & $\begin{array}{l}148 \\
(84)\end{array}$ & $\begin{array}{l}233 \\
(49)\end{array}$ & $\begin{array}{l}247 \\
(55)\end{array}$ & $\begin{array}{l}153 \\
(69)\end{array}$ & $\begin{array}{l}83 \\
(54)\end{array}$ \\
\hline $\begin{array}{l}\text { Amount contributed } \\
\text { (conditional, exclusive of credit) }\end{array}$ & $\begin{array}{l}558 \\
(40)\end{array}$ & $\begin{array}{l}504 \\
(50)\end{array}$ & $\begin{array}{l}439 \\
(19)\end{array}$ & $\begin{array}{l}119 \\
(39)\end{array}$ & $\begin{array}{c}54 \\
(65)\end{array}$ & $\begin{array}{c}65 \\
(45)\end{array}$ & $\begin{array}{l}-10 \\
(48)\end{array}$ & $\begin{array}{c}59 \\
(56)\end{array}$ & $\begin{array}{l}-81 \\
(50)\end{array}$ \\
\hline $\begin{array}{l}\text { Fraction open an X-IRA } \\
\text { with less than } \$ 450\end{array}$ & $\begin{array}{l}6.09 \\
(0.61)\end{array}$ & $\begin{array}{c}2.27 \\
(0.37)\end{array}$ & $\begin{array}{c}2.63 \\
(0.14)\end{array}$ & $\begin{array}{c}3.46 \\
(0.46)\end{array}$ & $\begin{array}{l}3.82 \\
(0.71)\end{array}$ & $\begin{array}{l}-0.36 \\
(0.42)\end{array}$ & $\begin{array}{c}3.40 \\
(0.56)\end{array}$ & $\begin{array}{c}3.78 \\
(0.71)\end{array}$ & $\begin{array}{l}-0.39 \\
(0.52)\end{array}$ \\
\hline $\begin{array}{l}\text { Fraction open an X-IRA } \\
\text { with } \$ 450 \text { or more }\end{array}$ & $\begin{array}{c}4.10 \\
(0.50)\end{array}$ & $\begin{array}{c}4.16 \\
(0.50)\end{array}$ & $\begin{array}{c}0.71 \\
(0.07)\end{array}$ & $\begin{array}{c}3.39 \\
(0.28)\end{array}$ & $\begin{array}{l}-0.06 \\
(0.71)\end{array}$ & $\begin{array}{c}3.45 \\
(0.28)\end{array}$ & $\begin{array}{c}2.71 \\
(0.34)\end{array}$ & $\begin{array}{l}-0.01 \\
(0.70)\end{array}$ & $\begin{array}{c}2.79 \\
(0.34)\end{array}$ \\
\hline Observations & 1,561 & 1,588 & 12,703 & & & & & & \\
\hline \multicolumn{10}{|c|}{ Panel B: Filers with refund above $\$ 1000$} \\
\hline $\begin{array}{l}\text { Fraction open an X-IRA } \\
\quad \text { (percentage) }\end{array}$ & $\begin{array}{l}12.29 \\
(0.95)\end{array}$ & $\begin{array}{c}7.81 \\
(0.79)\end{array}$ & $\begin{array}{c}4.12 \\
(0.20)\end{array}$ & $\begin{array}{c}8.18 \\
(0.66)\end{array}$ & $\begin{array}{c}4.48 \\
(1.23)\end{array}$ & $\begin{array}{c}3.69 \\
(0.64)\end{array}$ & $\begin{array}{c}7.37 \\
(0.81)\end{array}$ & $\begin{array}{c}4.66 \\
(1.23)\end{array}$ & $\begin{array}{c}2.79 \\
(0.78)\end{array}$ \\
\hline $\begin{array}{l}\text { Amount contributed } \\
\text { (unconditional, dollars) }\end{array}$ & $\begin{array}{l}63.75 \\
(6.82)\end{array}$ & $\begin{array}{l}47.43 \\
(6.42)\end{array}$ & $\begin{array}{l}16.51 \\
(1.08)\end{array}$ & $\begin{array}{l}47.24 \\
(3.89)\end{array}$ & $\begin{array}{l}16.32 \\
(9.37)\end{array}$ & $\begin{array}{l}30.92 \\
(3.83)\end{array}$ & $\begin{array}{l}37.40 \\
(4.76)\end{array}$ & $\begin{array}{l}16.75 \\
(9.32)\end{array}$ & $\begin{array}{l}20.84 \\
(4.65)\end{array}$ \\
\hline $\begin{array}{l}\text { Amount contributed } \\
\text { (inclusive of match, unconditional) }\end{array}$ & $\begin{array}{l}93.3 \\
(9.37)\end{array}$ & $\begin{array}{c}47.4 \\
(6.42)\end{array}$ & $\begin{array}{c}16.5 \\
(1.08)\end{array}$ & $\begin{array}{c}76.8 \\
(4.50)\end{array}$ & $\begin{array}{c}45.9 \\
(11.43)\end{array}$ & $\begin{array}{c}30.9 \\
(3.83)\end{array}$ & $\begin{array}{c}67.0 \\
(5.50)\end{array}$ & $\begin{array}{c}46.6 \\
(11.35)\end{array}$ & $\begin{array}{c}20.8 \\
(4.65)\end{array}$ \\
\hline $\begin{array}{l}\text { Amount contributed } \\
\text { (conditional) }\end{array}$ & $\begin{array}{l}522 \\
(39)\end{array}$ & $\begin{array}{l}621 \\
(56)\end{array}$ & $\begin{array}{l}428 \\
(18)\end{array}$ & $\begin{array}{c}94 \\
(37)\end{array}$ & $\begin{array}{l}-99 \\
(66)\end{array}$ & $\begin{array}{l}193 \\
(45)\end{array}$ & $\begin{array}{l}-16 \\
(48)\end{array}$ & $\begin{array}{l}-95 \\
(60)\end{array}$ & $\begin{array}{c}66 \\
(51)\end{array}$ \\
\hline $\begin{array}{l}\text { Amount contributed } \\
\text { (conditional, inclusive of match) }\end{array}$ & $\begin{array}{l}765 \\
(49)\end{array}$ & $\begin{array}{l}621 \\
(56)\end{array}$ & $\begin{array}{l}428 \\
(18)\end{array}$ & $\begin{array}{l}337 \\
(42)\end{array}$ & $\begin{array}{l}144 \\
(77)\end{array}$ & $\begin{array}{l}193 \\
(45)\end{array}$ & $\begin{array}{l}227 \\
(53)\end{array}$ & $\begin{array}{l}148 \\
(69)\end{array}$ & $\begin{array}{c}66 \\
(51)\end{array}$ \\
\hline $\begin{array}{l}\text { Amount contributed } \\
\text { (conditional, exclusive of credit) }\end{array}$ & $\begin{array}{l}522 \\
(39)\end{array}$ & $\begin{array}{l}465 \\
(42)\end{array}$ & $\begin{array}{l}428 \\
(18)\end{array}$ & $\begin{array}{c}94 \\
(37)\end{array}$ & $\begin{array}{c}57 \\
(60)\end{array}$ & $\begin{array}{c}38 \\
(42)\end{array}$ & $\begin{array}{l}-16 \\
(48)\end{array}$ & $\begin{array}{c}62 \\
(55)\end{array}$ & $\begin{array}{l}-88 \\
(47)\end{array}$ \\
\hline $\begin{array}{l}\text { Fraction open an X-IRA } \\
\text { with less than } \$ 450\end{array}$ & $\begin{array}{c}7.56 \\
(0.76)\end{array}$ & $\begin{array}{c}2.83 \\
(0.49)\end{array}$ & $\begin{array}{l}3.27 \\
(0.18)\end{array}$ & $\begin{array}{l}4.29 \\
(0.58)\end{array}$ & $\begin{array}{l}4.73 \\
(0.91)\end{array}$ & $\begin{array}{l}-0.44 \\
(0.55)\end{array}$ & $\begin{array}{l}4.33 \\
(0.71)\end{array}$ & $\begin{array}{l}4.87 \\
(0.91)\end{array}$ & $\begin{array}{l}-0.50 \\
(0.67)\end{array}$ \\
\hline $\begin{array}{l}\text { Fraction open an X-IRA } \\
\text { with } \$ 450 \text { or more }\end{array}$ & $\begin{array}{l}4.73 \\
(0.61)\end{array}$ & $\begin{array}{c}4.98 \\
(0.64)\end{array}$ & $\begin{array}{c}0.85 \\
(0.09)\end{array}$ & $\begin{array}{c}3.89 \\
(0.34)\end{array}$ & $\begin{array}{l}-0.24 \\
(0.88)\end{array}$ & $\begin{array}{c}4.13 \\
(0.35)\end{array}$ & $\begin{array}{c}3.04 \\
(0.42)\end{array}$ & $\begin{array}{l}-0.21 \\
(0.88)\end{array}$ & $\begin{array}{c}3.28 \\
(0.42)\end{array}$ \\
\hline Observations & 1,204 & 1,165 & 9,691 & & & & & & \\
\hline
\end{tabular}


Table 5-Effect of Presentation: Match versus Credit (Continued)

\begin{tabular}{|c|c|c|c|c|c|c|c|c|c|}
\hline & \multicolumn{3}{|c|}{ Means } & \multicolumn{3}{|c|}{ Differences } & \multicolumn{3}{|c|}{$\begin{array}{l}\text { Differences adjusted } \\
\text { for covariates }\end{array}$} \\
\hline & $\begin{array}{l}\text { Match } \\
\text { group }\end{array}$ & $\begin{array}{l}\text { Credit } \\
\text { group }\end{array}$ & $\begin{array}{l}\text { Control } \\
\text { group }\end{array}$ & $\begin{array}{l}\text { Match } \\
\text { versus } \\
\text { control }\end{array}$ & $\begin{array}{l}\text { Match } \\
\text { versus } \\
\text { credit }\end{array}$ & $\begin{array}{l}\text { Credit } \\
\text { versus } \\
\text { control }\end{array}$ & $\begin{array}{l}\text { Match } \\
\text { versus } \\
\text { control }\end{array}$ & $\begin{array}{l}\text { Match } \\
\text { versus } \\
\text { credit }\end{array}$ & $\begin{array}{l}\text { Credit } \\
\text { versus } \\
\text { control }\end{array}$ \\
\hline & (1) & (2) & (3) & (4) & (5) & (6) & (7) & $(8)$ & (9) \\
\hline \multicolumn{10}{|c|}{ Panel C: Filers with return between March 5 and April 1, 2006} \\
\hline $\begin{array}{l}\text { Fraction open an X-IRA } \\
\quad \text { (percentage) }\end{array}$ & $\begin{array}{l}13.54 \\
(2.27)\end{array}$ & $\begin{array}{c}7.92 \\
(1.75)\end{array}$ & $\begin{array}{c}1.93 \\
(0.32)\end{array}$ & $\begin{array}{l}11.61 \\
(1.21)\end{array}$ & $\begin{array}{c}5.62 \\
(2.85)\end{array}$ & $\begin{array}{c}5.99 \\
(1.09)\end{array}$ & $\begin{array}{l}10.66 \\
(1.48)\end{array}$ & $\begin{array}{c}5.45 \\
(2.85)\end{array}$ & $\begin{array}{c}5.03 \\
(1.34)\end{array}$ \\
\hline $\begin{array}{l}\text { Amount contributed } \\
\text { (unconditional, dollars) }\end{array}$ & $\begin{array}{l}110.70 \\
(23.33)\end{array}$ & $\begin{array}{l}101.13 \\
(28.43)\end{array}$ & $\begin{array}{l}13.45 \\
(3.62)\end{array}$ & $\begin{array}{c}97.25 \\
(13.14)\end{array}$ & $\begin{array}{c}9.57 \\
(36.97)\end{array}$ & $\begin{array}{c}87.68 \\
(14.35)\end{array}$ & $\begin{array}{c}77.18 \\
(15.95)\end{array}$ & $\begin{array}{c}7.23 \\
(36.94)\end{array}$ & $\begin{array}{c}68.26 \\
(17.56)\end{array}$ \\
\hline $\begin{array}{l}\text { Amount contributed } \\
\text { (inclusive of match, unconditional) }\end{array}$ & $\begin{array}{c}166.1 \\
(35.00)\end{array}$ & $\begin{array}{c}101.1 \\
(28.43)\end{array}$ & $\begin{array}{c}13.4 \\
(3.62)\end{array}$ & $\begin{array}{c}152.6 \\
(16.07)\end{array}$ & $\begin{array}{c}64.9 \\
(44.90)\end{array}$ & $\begin{array}{c}87.7 \\
(14.35)\end{array}$ & $\begin{array}{c}132.3 \\
(19.53)\end{array}$ & $\begin{array}{c}63.1 \\
(44.83)\end{array}$ & $\begin{array}{c}68.3 \\
(17.56)\end{array}$ \\
\hline $\begin{array}{l}\text { Amount contributed } \\
\text { (conditional) }\end{array}$ & $\begin{array}{c}845 \\
(106)\end{array}$ & $\begin{array}{l}1348 \\
(229)\end{array}$ & $\begin{array}{c}787 \\
(162)\end{array}$ & $\begin{array}{c}59 \\
(195)\end{array}$ & $\begin{array}{l}-503 \\
(224)\end{array}$ & $\begin{array}{c}562 \\
(275)\end{array}$ & $\begin{array}{l}-266 \\
(243)\end{array}$ & $\begin{array}{l}-499 \\
(199)\end{array}$ & $\begin{array}{c}143 \\
(349)\end{array}$ \\
\hline $\begin{array}{l}\text { Amount contributed } \\
\text { (conditional, inclusive of match) }\end{array}$ & $\begin{array}{l}1268 \\
(159)\end{array}$ & $\begin{array}{l}1348 \\
(229)\end{array}$ & $\begin{array}{c}787 \\
(162)\end{array}$ & $\begin{array}{l}481 \\
(227)\end{array}$ & $\begin{array}{l}-81 \\
(272)\end{array}$ & $\begin{array}{c}562 \\
(275)\end{array}$ & $\begin{array}{c}163 \\
(276)\end{array}$ & $\begin{array}{l}-67 \\
(233)\end{array}$ & $\begin{array}{c}143 \\
(349)\end{array}$ \\
\hline $\begin{array}{l}\text { Amount contributed } \\
\text { (conditional, exclusive of credit) }\end{array}$ & $\begin{array}{c}845 \\
(106)\end{array}$ & $\begin{array}{l}1010 \\
(197)\end{array}$ & $\begin{array}{l}787 \\
(162)\end{array}$ & $\begin{array}{c}59 \\
(195)\end{array}$ & $\begin{array}{l}-165 \\
(205)\end{array}$ & $\begin{array}{c}224 \\
(260)\end{array}$ & $\begin{array}{l}-266 \\
(243)\end{array}$ & $\begin{array}{l}-160 \\
(183)\end{array}$ & $\begin{array}{l}-195 \\
(334)\end{array}$ \\
\hline $\begin{array}{l}\text { Fraction open an X-IRA } \\
\text { with less than } \$ 450\end{array}$ & $\begin{array}{c}3.49 \\
(1.22)\end{array}$ & $\begin{array}{c}1.67 \\
(0.83)\end{array}$ & $\begin{array}{l}1.05 \\
(0.24)\end{array}$ & $\begin{array}{l}2.45 \\
(0.80)\end{array}$ & $\begin{array}{c}1.83 \\
(1.46)\end{array}$ & $\begin{array}{c}0.62 \\
(0.72)\end{array}$ & $\begin{array}{l}2.07 \\
(0.98)\end{array}$ & $\begin{array}{c}1.71 \\
(1.48)\end{array}$ & $\begin{array}{c}0.26 \\
(0.89)\end{array}$ \\
\hline $\begin{array}{l}\text { Fraction open an X-IRA } \\
\text { with } \$ 450 \text { or more }\end{array}$ & $\begin{array}{l}10.04 \\
(1.99)\end{array}$ & $\begin{array}{c}6.25 \\
(1.57)\end{array}$ & $\begin{array}{c}0.88 \\
(0.22)\end{array}$ & $\begin{array}{l}9.16 \\
(0.94)\end{array}$ & $\begin{array}{c}3.79 \\
(2.52)\end{array}$ & $\begin{array}{c}5.37 \\
(0.83)\end{array}$ & $\begin{array}{r}8.59 \\
(1.14)\end{array}$ & $\begin{array}{c}3.74 \\
(2.51)\end{array}$ & $\begin{array}{c}4.77 \\
(1.02)\end{array}$ \\
\hline Observations & 229 & 240 & 1,813 & & & & & & \\
\hline
\end{tabular}

Notes: The differences in columns 7-9 are regression adjusted for the same covariates as in Table 2. Standard errors in parentheses.

between take-up rates for the match and the credit rise as the tax season progresses (Figure 2).

The difference in take-up rates for the match and credit groups can be attributed almost entirely to the lower probability, in the credit group, of opening an X-IRA with contributions between $\$ 300$ and $\$ 450$, with no corresponding increase at higher contribution levels (panel A, Table 5). As noted above, contributions below $\$ 450$ did not trigger the credit rebate. Thus, it appears as though filers correctly perceived that they would not get a credit for small contributions. They are no more likely to open a small X-IRA in the credit group than in the control group. But filers did not realize that if their intent was to have only $\$ 300$ in out-of-pocket costs, they could achieve this objective with a $\$ 450$ contribution, which would be offset by a $\$ 150$ rebate. One possibility is that credit group participants were severely credit constrained and thus could not contribute $\$ 450$ on the spot. However, panel B of Table 5 restricts the sample to taxpayers with a refund of at least \$1,000 and obtains almost identical results, casting doubt on the credit constraint explanation. 19

\footnotetext{
${ }^{19}$ It is conceivable that tax filers have already spent their tax refund in advance using expensive credit and hence are not able to contribute into an X-IRA. Another possibility is that clients do not trust a private company
} 


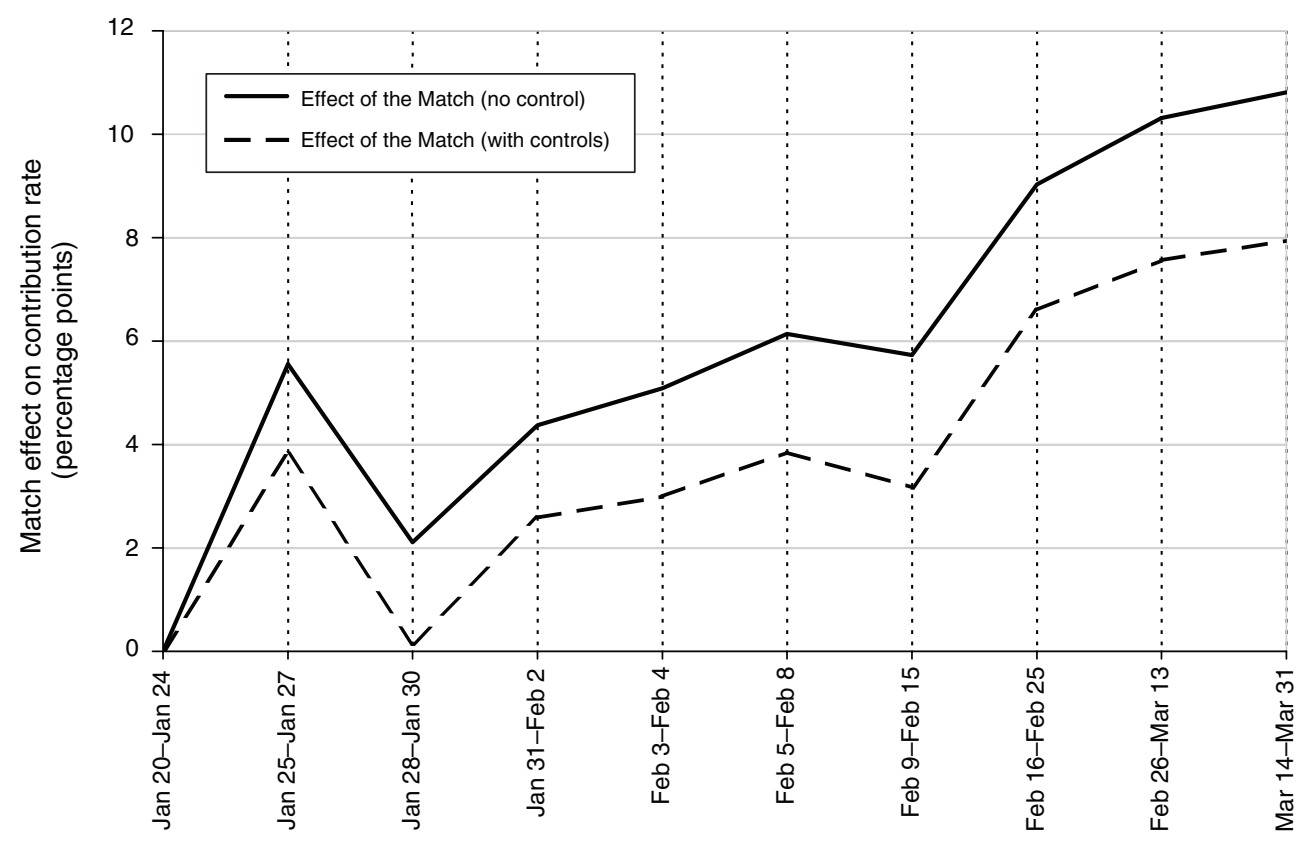

Filing dates deciles

Figure 1. Effect of the Match on X-IRA Contribution Rates Over Time

Notes: The figure reports the coefficients of a regression of an IRA contribution dummy on filing dates decile dummies interacted with the match treatment dummy. The regression also includes filing dummies. The omitted decile dummy is the first decile (January 20-24). The bold line does not include any additional controls. The dashed line includes additional control variables (income quartile dummies, presence of investment income, home ownership, tax refund above $\$ 500$, presence of dependents, and office group) and the interaction of those control variables with the match dummy. Standard errors are around 1 percentage point for each plotted coefficients so that all coefficients (except those for Jan 28-30) are significant.

Some of the differing take-up responses to the match and credit may arise because filers mistakenly perceive the 33 percent credit as equivalent to a 33 percent match and hence less attractive than a 50 percent match. ${ }^{20}$ Evidence on this issue can be gleaned from our 2005 experiment, where 7.7 percent of eligible households took up the 20 percent match, compared to 14 percent who took up the 50 percent match. Among clients in our 2006 sample who filed between March 5 and April 1, 2006, and who were in the match versus credit offices, take-up rates were about the same for the 50 percent match in 2006 ( 13.54 percentage points) as in 2005 and were only slightly higher for the 33 percent credit in 2006 ( 7.92 percentage points) than for the 20 percent match in 2005 (panel C, Table 4). Hence, the response to the credit seems

to send the rebate check. It is unclear, however, why a promise to mail a future rebate check should be viewed as less trustworthy than a promise to provide a future matching contribution. And, even if the rebate promise were somehow viewed as less believable, the money in the account would still belong to the taxpayer. Thus, someone who would have contributed $\$ 300$ with no offer, but chose to contribute $\$ 450$ with the credit rebate offer, could always withdraw the extra $\$ 150$ (at no cost, if they opened a Roth IRA) if the rebate check was not delivered.

${ }^{20}$ Davis and Millner (2006) make this point in the context of charitable giving. Some tax professionals, who are on average more financially educated than their clients, argued along those lines and thought that the credit was less advantageous than the match. 


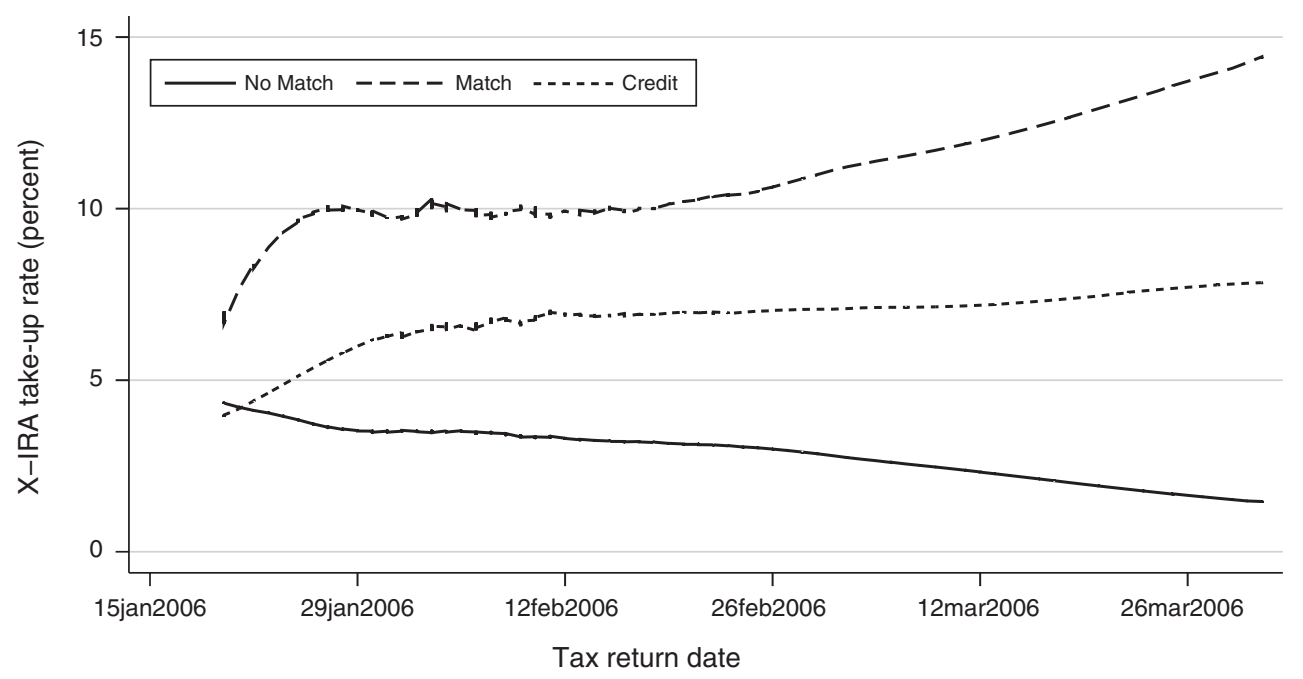

Figure 2. Time Series of X-IRA TAKe-UP-Match And Credit

to be even smaller than what would have been predicted by treating the 33 percent credit as a 33 percent match.

Eckel and Grossman (2003, 2005, 2006a, b, c) argue that matching schemes might generate larger effects in the context of charitable giving because individuals perceive the match as sharing the effort whereas the credit feels like the individual shoulders all the contributions. For retirement saving, however, unlike charitable giving, there is no direct external effect of contributions on the common good, so this feeling cannot be the explanation in our context.

Another possibility arises from the fact that, unlike in the charitable giving experiments, in our experiments, filers had to wait a couple of weeks for the credit rebate. In other words, contributing $\$ 450$ out-of-pocket and then receiving $\$ 150$ back in a few weeks may feel more painful than simply contributing $\$ 300$ under the match scenario and obtaining the same $\$ 450 \mathrm{X}$-IRA total contribution. This differential effect could be due to loss aversion effects proposed by the prospect theory of Daniel Kahneman and Amos Tversky (1979). Alternatively, and as discussed above, individuals might face high costs of cashing the rebate check or might face a substantial probability of losing the check or having to share the proceeds with household members. So, the cost is real rather than psychological. The important point, however, is that such friction costs are generally ignored in economic studies although they might end up having very large effects in real situations.

The difference in contribution levels between the match and credit group is illustrated in Figure 3, which shows the cumulative distributions of X-IRA contributions across the treatment groups. Contributions are largest in the match group (when including the match) and smallest in the control group. The distributions of contributions in the credit group and the match group (exclusive of the match) are fairly close above $\$ 300$.

Although the credit rebate in the experiment is somewhat different from the saver's credit (the latter is nonrefundable and varies with income level), the federal 


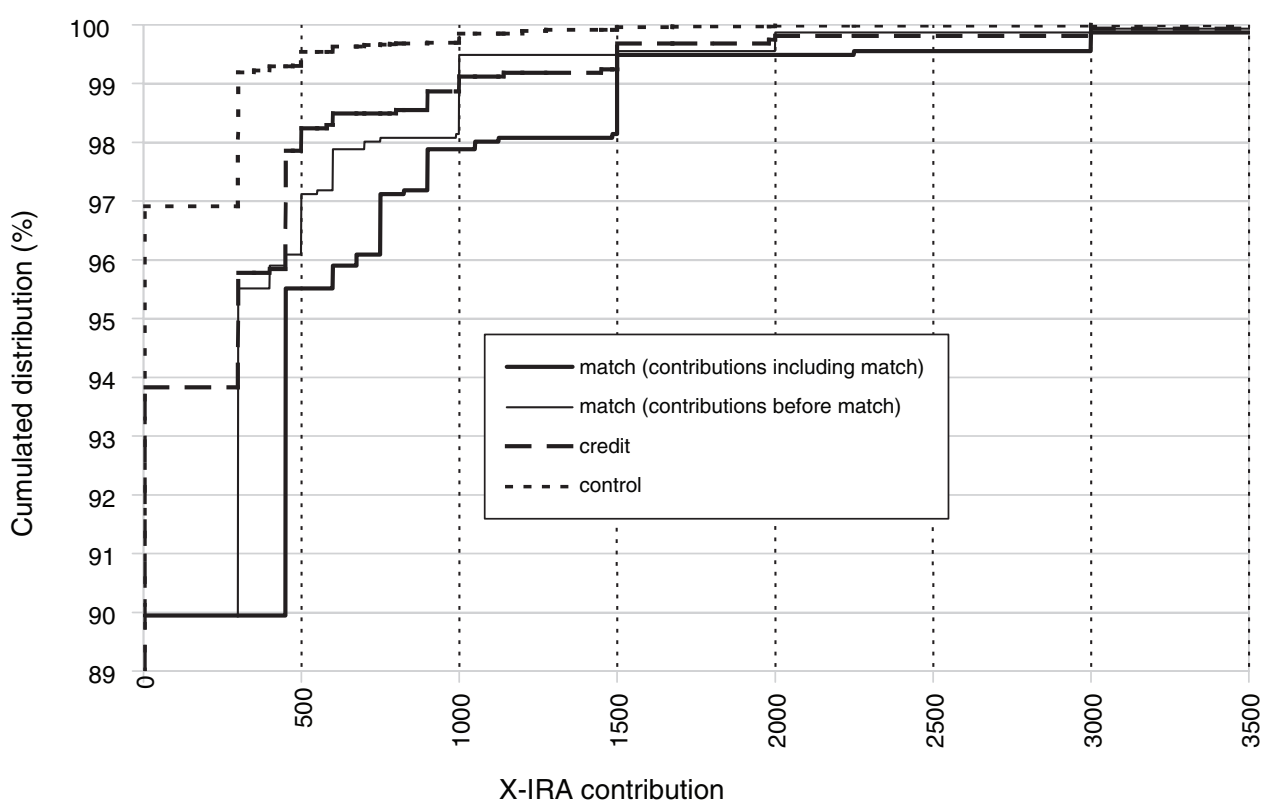

Figure 3. Match vs. Credit Presentation Cumulative Distributions of X-IRA Take-up

Notes: The figure reports the cumulated distributions of X-IRA take-up (including zeros) for the match presentation group, the credit presentation group, and the control group.In the case of the match group, we report cumulative distributions including and excluding the match.

saver's credit and our credit rebate provide cash back or a reduction in tax liability rather than a matching contribution to the account. Thus, as discussed further in the conclusion, the differences in taxpayer responses to the match and credit groups has implications for the design of public policy.

\section{Advance Notification}

The experiments described above took place without any advance notification to clients. ${ }^{21}$ Field observations strongly suggest that the vast majority of those clients did not know about the matching program prior to their visit to the H\&R Block office. The potential effects of advance notification are interesting, however, for two reasons. First, such information could alter taxpayer responses. For example, focus group discussions following the 2005 experiment revealed that some filers had turned down the 50 percent match offer because, before coming in to the H\&R Block office to file their returns, they had already made plans to use their refunds for specific purposes. Second, federal policies could be redesigned at low transaction and revenue costs to allow people to know in advance that they will be eligible for a particular subsidy rate and give them the chance to plan ahead.

\footnotetext{
${ }^{21}$ Specifically, clients receiving advance notification were excluded from the analyses presented in the earlier sections of this paper.
} 
Table 6 shows descriptive data for offices where some filers were scheduled to be called in advance. The first two columns report information by call status. The two panels report information by match status. The sample excludes taxpayers in the "Do not call" registry regardless of whether they were scheduled to be called. Even after those filers are excluded, only about 30 percent of those who were to be called were actually reached. Although call status was determined randomly, based on the last two digits of the customer's SSN, there are small but statistically significant differences in the percent married and the mean adjusted gross income between those scheduled to receive a call and those with no call scheduled. We attribute these differences to random assignment (also since married taxpayers have higher AGI than other taxpayers, it is not surprising to have both of these variables showing lack of balance at the same time). The fraction reached was similar in the match and no match groups, suggesting that we successfully implemented calling procedures that were blind to treatment status. Perhaps surprisingly, in the matc group, the calls had no impact on the fraction of 2005 H\&R Block customers who returned to have their taxes done in 2006. In the no match group, the calls seem to have had a small positive impact on the fraction returning to H\&R Block, though the t-stat on this impact is slightly below two.

For the analysis of the impact of the calls (rows 5-7 of each panel), we restrict our sample to clients who return to Block in 2006. This restriction allows our sample to be comparable to the samples used in the earlier sections of the paper (which include only clients who returned to Block in 2006 and not nonreturning clients), and it allows us to regression adjust our results using the same specifications used for the other results (most of our covariates come from information collected during the 2005 tax interview and are therefore not available for clients who did not return in 2006). Our judgment is that given that the calls had little or no impact on who returned, the benefits of presenting comparable results outweigh the potential selection bias that could be present if the calls affected who returned to Block offices.

Among matched filers, being scheduled to be called raised take-up by a statistically significant 2.1 percentage points (column 3)! 22 Controlling for the covariates, the coefficient is essentially the same (1.9 percentage points). These are underestimates of the effect of actually receiving a call, however, since there is no reason why attempting to call a filer would have an effect if the filer was not reached. Among those called, the subsample of those reached is not random, so we cannot simply compare those who are reached and those who are not scheduled to be called. Since the difference in take-up between those who were scheduled to be called and those who were not can be entirely attributed to the effect of the call, the "attempt to call" variable can be used as an instrument for the dummy indicating whether someone has been reached, to generate an estimate of the "effect of the treatment on the treated" (TOT) ${ }^{23}$ The TOT effect is large. Receiving a call raised take-up by 6.9 percentage points (unadjusted) and 6.1 percentage points (regression adjusted). This

\footnotetext{
${ }^{22}$ As with the earlier results for the "pure" match and the match versus credit comparisons, take-up rates among those who were notified in advance and who received the match rose as the tax season progressed.

${ }^{23}$ The Wald estimate is obtained by dividing the difference between the participation rates in the two groups by the fraction of those who were reached.
} 
Table 6-Effect of Advance Notification

\begin{tabular}{|c|c|c|c|c|c|c|}
\hline & $\begin{array}{l}\text { Mean, call } \\
\text { scheduled }\end{array}$ & $\begin{array}{c}\text { Mean, } \\
\text { no call } \\
\text { scheduled }\end{array}$ & Difference & $\begin{array}{c}\text { Adjusted } \\
\text { difference }\end{array}$ & $\begin{array}{c}\text { Effect of } \\
\text { being } \\
\text { reached }\end{array}$ & $\begin{array}{c}\text { Effect of } \\
\text { being reached, } \\
\text { adjusted }\end{array}$ \\
\hline & (1) & (2) & (3) & (4) & (5) & (6) \\
\hline \multicolumn{7}{|c|}{ Panel A: Filers who received the match in 2006} \\
\hline Married & $\begin{array}{c}0.21 \\
(0.006)\end{array}$ & $\begin{array}{c}0.19 \\
(0.004)\end{array}$ & $\begin{array}{c}0.020 \\
(0.008)\end{array}$ & & & \\
\hline 2004 adjusted gross income & $\begin{array}{c}33,743 \\
(491)\end{array}$ & $\begin{array}{c}31,606 \\
(314)\end{array}$ & $\begin{array}{l}2,137 \\
(559)\end{array}$ & & & \\
\hline Fraction reached & $\begin{array}{c}0.28 \\
(0.007)\end{array}$ & $\begin{array}{c}0.00 \\
(0.000)\end{array}$ & $\begin{array}{c}0.28 \\
(0.005)\end{array}$ & & & \\
\hline Fraction filing returns with $H \& R$ Block & $\begin{array}{c}0.64 \\
(0.007)\end{array}$ & $\begin{array}{c}0.64 \\
(0.005)\end{array}$ & $\begin{array}{l}-0.002 \\
(0.009)\end{array}$ & & & \\
\hline Percent contributed to X-IRA & $\begin{array}{c}10.4 \\
(0.71)\end{array}$ & $\begin{array}{c}8.3 \\
(0.47)\end{array}$ & $\begin{array}{c}2.1 \\
(0.83)\end{array}$ & $\begin{array}{c}1.9 \\
(0.99)\end{array}$ & $\begin{array}{c}6.9 \\
(2.69)\end{array}$ & $\begin{array}{c}6.1 \\
(3.24)\end{array}$ \\
\hline $\begin{array}{l}\text { Amount contributed (dollars) } \\
\text { (unconditional) }\end{array}$ & $\begin{array}{l}95.3 \\
(9.13)\end{array}$ & $\begin{array}{c}67.8 \\
(5.44)\end{array}$ & $\begin{array}{c}27.4 \\
(10.01)\end{array}$ & $\begin{array}{c}22.5 \\
(11.91)\end{array}$ & $\begin{array}{c}89.5 \\
(32.56)\end{array}$ & $\begin{array}{c}73.7 \\
(38.94)\end{array}$ \\
\hline $\begin{array}{l}\text { Amount contributed (dollars) } \\
\text { (conditional) }\end{array}$ & $\begin{array}{l}923.0 \\
(61.59)\end{array}$ & $\begin{array}{l}846.6 \\
(47.51)\end{array}$ & $\begin{array}{c}76.4 \\
(76.84)\end{array}$ & $\begin{array}{c}26.6 \\
(82.76)\end{array}$ & $\begin{array}{c}182.7 \\
(182.29)\end{array}$ & $\begin{array}{c}66.0 \\
(205.25)\end{array}$ \\
\hline Observations & 1,831 & 3,494 & & & & \\
\hline
\end{tabular}

Panel B: Filers who did not receive the match in 2006

\begin{tabular}{|c|c|c|c|c|c|c|}
\hline Married & $\begin{array}{c}0.21 \\
(0.006)\end{array}$ & $\begin{array}{c}0.20 \\
(0.003)\end{array}$ & $\begin{array}{c}0.013 \\
(0.007)\end{array}$ & & & \\
\hline 2004 adjusted gross income & $\begin{array}{c}33,336 \\
(466)\end{array}$ & $\begin{array}{c}31,987 \\
(209)\end{array}$ & $\begin{array}{l}1,350 \\
(498)\end{array}$ & & & \\
\hline Fraction reached & $\begin{array}{c}0.32 \\
(0.007)\end{array}$ & $\begin{array}{c}0.00 \\
(0.000)\end{array}$ & $\begin{array}{c}0.32 \\
(0.003)\end{array}$ & & & \\
\hline Fraction filing returns with $\mathrm{H} \& \mathrm{R}$ Block & $\begin{array}{c}0.65 \\
(0.007)\end{array}$ & $\begin{array}{c}0.63 \\
(0.003)\end{array}$ & $\begin{array}{c}0.015 \\
(0.008)\end{array}$ & & & \\
\hline Percent contributed to X-IRA & $\begin{array}{c}3.0 \\
(0.40)\end{array}$ & $\begin{array}{c}2.9 \\
(0.18)\end{array}$ & $\begin{array}{c}0.1 \\
(0.44)\end{array}$ & $\begin{array}{c}0.2 \\
(0.47)\end{array}$ & $\begin{array}{c}0.4 \\
(1.32)\end{array}$ & $\begin{array}{c}0.6 \\
(1.42)\end{array}$ \\
\hline $\begin{array}{l}\text { Amount contributed (dollars) } \\
\text { (unconditional) }\end{array}$ & $\begin{array}{c}18.0 \\
(5.14)\end{array}$ & $\begin{array}{c}12.7 \\
(1.04)\end{array}$ & $\begin{array}{c}5.3 \\
(3.27)\end{array}$ & $\begin{array}{c}6.6 \\
(3.51)\end{array}$ & $\begin{array}{c}16.1 \\
(9.90)\end{array}$ & $\begin{array}{c}20.1 \\
(10.63)\end{array}$ \\
\hline $\begin{array}{l}\text { Amount contributed (dollars) } \\
\text { (conditional) }\end{array}$ & $\begin{array}{c}687.3 \\
(171.45)\end{array}$ & $\begin{array}{l}489.8 \\
(23.07)\end{array}$ & $\begin{array}{l}197.5 \\
(93.50)\end{array}$ & $\begin{array}{l}172.5 \\
(98.72)\end{array}$ & $\begin{array}{c}488.6 \\
(229.60)\end{array}$ & $\begin{array}{c}432.9 \\
(246.60)\end{array}$ \\
\hline Observations & 1,796 & 8,379 & & & & \\
\hline
\end{tabular}

Notes: The variable "call attempted" is 1 for all individuals who were scheduled to be called. The sample for this table excludes all individuals in the "do not call" directory (irrespective of whether they were scheduled to be called). Columns 4 and 6 are instrumental variable regressions, where the endogenous regressor is a dummy equal to 1 if the person was reached, and the instrument is the "call attempted" dummy. Columns 4 and 6 control for the same variables as in Table 2 (in column 6, all the control variables are also in the instrument set). There is no adjusted regression for the indicator for whether the taxpayer filed a return with H\&R Block, since the control variables are not defined for taxpayers who did not. Standard errors in parentheses. 
effect is larger than the "pure" effect of the match itself (5.72 percentage points) as shown in Table 2 ${ }^{24}$ In contrast, receiving a call had no effect on take-up among filers who did not receive a match. Also, advance notification had little effect on contribution levels, given take-up, for either the matched or the unmatched group (these estimates are not very precise).

An alternative way to analyze the joint impact of the match and the advance calling is to pool both the match and no match samples (which were analyzed separately in the two panels of Table 6) and to run difference-in-differences regressions. Table 7 shows that all of the key results about advance notification are robust to this alternative specification. In panel A, X-IRA take-up rates and contribution levels are regressed on a dummy for whether the filer was scheduled to be called, whether she received a match, the interaction of the two, all of the characteristics in Table 2, and their interaction with being scheduled to be called. In column 1, the coefficient on the interaction between receiving a call and receiving a match is 1.62 , quite close to the difference between the regression adjusted impact of calling for those in the match group (1.9) and those in the no-match group (0.2) in column 4 of Table 6. Panel B presents an instrumental variables (IV) regression where the variables "call attempted" and "call attempted $\times$ match in 2006" are used as instruments for the variables "reached" and "reached $\times$ match in 2006 " - a specification comparable to the TOT specifications in Table 6. The phone call had no impact in the unmatched group, but increased take-up in the matched group by 4.93 percentage points; that is, it more than doubled the effect of the match, which was 3.56 percentage points. This is a striking result. The fact that a simple phone call and follow-up letter can more than double the take-up of a generous financial offer underlines the importance of advance notification.

The finding that advance notification raises the take-up of subsidies for saving may also help shed light on why the saver's credit generates such small take-up. Although people may know of the existence of the credit, the actual rate that will apply is difficult to forecast in advance. The credit is nonrefundable and thus depends on the presence of other deductions and credits. In addition, the rate changes quite abruptly over some ranges of income. As a result, filers may not know in advance whether they will qualify for the credit, let alone which rate will apply. The results for advance notification suggest that knowing these factors in advance can significantly boost the effects of matching incentives. It is also important to note that the call might also be perceived by tax filers as an encouragement to contribute to an $\mathrm{X}$-IRA as the match was presented by callers as an opportunity. Additional experiments varying the format of the call would be required to try and separate pure information effects (just knowing that a match will be offered) from encouragement effects (being told that the match is an opportunity).

\footnotetext{
${ }^{24}$ The mean X-IRA contribution rate for members of the match group who received calls was 8.9. With a TOT effect of the calls of 6.9, this implies that the mean for these individuals would have been 2 percent in the absence of the calls. Thus, the calls more than doubled take-up relative to the match-only outcome (which itself combines the impact of the match and the baseline contribution rate in the absence of the match) for these "compliers.” Lawrence F. Katz, Jeffrey R. Kling, and Jeffrey B. Liebman (2001) discuss the calculation of the control complier mean.
} 
Table 7-Effect of Advance Notification: Summary Regressions

\begin{tabular}{lccc}
\hline \hline & $\begin{array}{c}\text { Percent contributed } \\
\text { to an X-IRA }\end{array}$ & $\begin{array}{c}\text { Amount contributed } \\
\text { (unconditional) }\end{array}$ & $\begin{array}{c}\text { Amount contributed } \\
\text { (conditional) }\end{array}$ \\
\cline { 2 - 4 } & $(1)$ & $(2)$ & $(3)$ \\
\hline Panel A: Reduced form (excluding do not call) & & \\
Match & 3.56 & 23.4 & 318 \\
& $(0.32)$ & $(2.06)$ & $(60)$ \\
Call sample & -0.19 & 1.56 & 147 \\
& $(0.40)$ & $(2.61)$ & $(105)$ \\
Call sample $\times$ match & 1.62 & 9.8 & -82 \\
& $(0.60)$ & $(3.92)$ & $(124)$ \\
Observations & 23,214 & 36,291 & 834 \\
& & & \\
Panel B: IV (excluding do not call) & & 23.4 & 318 \\
Match & 3.56 & $(2.05)$ & $(60)$ \\
& $(0.32)$ & 4.94 & 419 \\
Reached & -0.56 & $(8.26)$ & $(297)$ \\
& $(1.16)$ & 35.7 & -254 \\
Reached $\times$ match & 4.93 & $(13.29)$ & $(340)$ \\
Observations & $(1.80)$ & 36,291 & 834 \\
\hline
\end{tabular}

Notes: This table excludes individuals in the "Do Not Call" directory in panels A and B and controls for all the variables included in Table 2. The "call sample" includes all those who were scheduled to be called (based on their social security number). The "reached" dummy indicates whether the individual was reached by phone. In panels $\mathrm{A}$ and $\mathrm{B}$, reached and reached $\times$ match are endogenous regressors; "call sample" and "call sample $\times$ match" are used as instruments. Standard errors in parentheses.

\section{Matches for Monthly Contributions}

The results in Tables 6 and 7 suggest that the ability to plan ahead is an important factor in the decision to take advantage of a financial incentive for retirement savings. In this section, we explore the effects of offering an alternative way for taxpayers to plan for the future. Table 8 reports data from the offices where filers were offered matches for monthly contributions to X-IRAs in addition to matches for one-time contributions. In general, monthly X-IRA contributions are not very popular. As shown in Table 8 , only 0.20 percent of filers chose to make monthly contributions in the control group in the offices where the monthly contribution match experiments were conducted. The match increased this proportion to 1.67 percent. However, of the 1.47 percentage point increase in take-up, 1.41 percentage points occur because of filers who made a matched, one-time contribution as well. As a result, the net effect on take-up of matching monthly contributions is essentially zero.

These results differ from recent studies of 401(k) plans (James J. Choi et al. 2002; Engelhardt and Kumar 2004; William E. Even and David A. MacPherson 2005; Huberman, Iyengar, and Jiang 2007), where matches have positive effects on the 
Table 8-Effect of Matches for Automatic Monthly Contributions

\begin{tabular}{lcccc}
\hline \hline & Match & No match & Difference & $\begin{array}{c}\text { Adjusted } \\
\text { difference }\end{array}$ \\
\cline { 2 - 5 } & $(1)$ & $(2)$ & $(3)$ & $(4)$ \\
\hline $\begin{array}{l}\text { Opened a one-time X-IRA } \\
\text { (percent) }\end{array}$ & 8.91 & 2.78 & 6.13 & 5.96 \\
$\begin{array}{l}\text { Opened a systematic X-IRA } \\
\text { (percent) }\end{array}$ & $(0.71)$ & $(0.14)$ & $(0.48)$ & $(0.55)$ \\
$\begin{array}{l}\text { Opened one-time and systematic X-IRA } \\
\text { (percent) }\end{array}$ & 1.67 & 0.20 & 1.47 & 1.47 \\
Observations & $(0.32)$ & $(0.04)$ & $(0.16)$ & $(0.18)$ \\
\hline
\end{tabular}

Notes: The differences in column 4 are regression adjusted for the same covariates as in Table 2. Standard errors in parentheses.

take-up of monthly $401(\mathrm{k})$ contributions ${ }^{25}$ The differing results are not due to dissimilar economic incentives. Fifty percent is the most common match rate in $401(\mathrm{k})$ plans. Rather, the differences suggest once again that "details" such as the differences between automatic deduction from payrolls versus bank accounts, whether it is a tax preparer or an employer making the deductions, peer effects, and so on, can play a key role in shaping saving behavior.

\section{Conclusion}

This paper provides evidence on individuals' savings choices in experiments where variation in informational and presentational characteristics is orthogonal to variation in the pure, underlying economic incentives. The results confirm that economic incentives significantly affect behavior, but also that holding such incentives constant, relatively small changes in the presentation of an incentive can have first-order effects on the effectiveness of the policy.

Presenting an economically equivalent subsidy as a match rather than credit rebate (or cash back) raises participation by 4 percentage points from a base of just over 6 percentage points. This shows that a purely presentational change can have a very large effect on the behavioral response elasticity, and hence that it is crucial to account for such presentational issues in estimating the effects of an incentive. Such a large difference cannot be easily explained within the rational model, and we have argued that a mix of confusion about subsidy rates and other factors such as very strong credit constraints must be part of the explanation.

Providing a phone call and letter a few months in advance of tax season more than doubles the effect of a 50 percent match. In contrast, advance notification had no effect on take-up of the IRA among filers who were ineligible for the match. These results show important interactions between incentives and information. Each can amplify the effects of the other, and providing one without the other may be

\footnotetext{
${ }^{25}$ See Choi, Laibson, and Madrian (2004) and Duflo et al. (2006) for discussion of the difficulty of interpreting earlier mixed findings on the effects of match rates on employee participation in $401(\mathrm{k})$ plans.
} 
ineffective, even in a situation where providing both is effective. These findings suggest that either many tax filers spend their refund in advance and therefore feel severely cash constrained at the time of tax preparation, even if they are receiving refunds, or that prior information helps build interest in the matching program. In either case, the conclusion is that prior information about a program is an important determinant of the size of the behavioral response and therefore that such informational variables should be included in empirical program evaluation.

Offering a matching subsidy for monthly contributions, which appears to be effective in raising take-up in workplace 401(k) plans, appears to have no impact on take-up of X-IRA plans. The differing impact of similar incentives in different environments again points to the importance of other factors, such as peer effects and automatic payroll deductions, that are present in 401(k) plans but not in the X-IRA presentation.

All of these effects represent the first experimental evidence on these issues in the context of saving for retirement. The findings are important for several reasons. First, they shed light on decision-making processes that people actually follow and in particular on the relative importance of economic incentives and psychological factors. Second, many of the informational and presentational characteristics of public policies can be changed at relatively low cost. Thus, the results give policy makers new and potentially powerful dimensions along which to alter public policy. The results also suggest that the content of a public policy can and should be considered to be much broader than just how it affects individuals' budget constraints. Third, optimal taxes and transfers depend crucially on the elasticity of household responses to public policies. Thus, a better understanding of efficient and equitable taxation can be obtained by examining the response to the presentation of incentives as well as the pure economic incentives themselves.

Our results suggest that the federal saver's credit could more effectively promote retirement saving if it were designed as a refundable, flat-rate match. The matching provision would raise total contributions (by the tax filer and the government) and could raise take-up relative to the current credit structure. A refundable, flat-rate subsidy would provide certainty, in advance, about the availability of the provision for tens of millions of households. There would still be uncertainty for taxpayers in or near the phase-out range of the credit, however. This could be eliminated by determining a filer's credit rate for the current year based on the taxpayer's situation (income, deductions, credits) in the previous year. That would allow tax filers to know early in the year, when they filed their taxes, the subsidy they would receive the following year. It might also make it more feasible to administer the subsidy through employers. Because saving for retirement is part of a lifetime decision plan and such savings are consumed during retirement, there should be less of a concern for basing a subsidy on last year's income rather than current income than there might be for a means-tested program that provides a current consumption safety net.

Finally, it is worth emphasizing that even when all the details are set in favorable ways, for example, a match presentation with advance notification, the take-up effects of a 50 percent matching offer remain quite modest, in the vicinity of 15 percent at a maximum, and are substantially smaller in the group of early filers. This suggests that even well advertised and well presented matching incentives for 
retirement saving can only address part of the issue of retirement security facing American families.

\section{APPENDIX}

Table A1-Effect of the Match and Credit on X-IRA TAKe-Up and Contributions

\begin{tabular}{|c|c|c|c|c|c|c|c|c|c|c|c|}
\hline & \multicolumn{5}{|c|}{ Match versus credit presentation } & \multicolumn{3}{|c|}{ Advance notification } & \multicolumn{3}{|c|}{ Match monthly contributions } \\
\hline & $\begin{array}{l}50 \% \\
\text { match } \\
(1)\end{array}$ & $\begin{array}{c}33 \% \\
\text { credit } \\
(2)\end{array}$ & $\begin{array}{c}\text { control } \\
\text { (3) }\end{array}$ & $\begin{array}{c}\text { Match } \\
\text { versus } \\
\text { credit } \\
\text { (4) }\end{array}$ & $\begin{array}{c}\text { Credit } \\
\text { versus } \\
\text { control } \\
\text { (5) }\end{array}$ & $\begin{array}{c}50 \% \\
\text { match } \\
(6)\end{array}$ & $\begin{array}{l}\text { No } \\
\text { match } \\
(7)\end{array}$ & $\begin{array}{c}\text { Difference } \\
\text { (8) }\end{array}$ & $\begin{array}{c}50 \% \\
\text { match } \\
(9)\end{array}$ & $\begin{array}{c}\text { No } \\
\text { match } \\
(10)\end{array}$ & $\begin{array}{c}\text { Difference } \\
\text { (11) }\end{array}$ \\
\hline $\begin{array}{c}\text { Opened X-IRA } \\
\text { (percentage) }\end{array}$ & $\begin{array}{l}10.19 \\
(0.77)\end{array}$ & $\begin{array}{c}6.42 \\
(0.62)\end{array}$ & $\begin{array}{c}3.34 \\
(0.16)\end{array}$ & $\begin{array}{c}3.76 \\
(0.98)\end{array}$ & $\begin{array}{c}3.09 \\
(0.50)\end{array}$ & $\begin{array}{c}9.12 \\
(0.37)\end{array}$ & $\begin{array}{c}2.81 \\
(0.15)\end{array}$ & $\begin{array}{c}6.31 \\
(0.34)\end{array}$ & $\begin{array}{l}9.09 \\
(0.72)\end{array}$ & $\begin{array}{c}2.94 \\
(0.15)\end{array}$ & $\begin{array}{c}6.15 \\
(0.49)\end{array}$ \\
\hline $\begin{array}{l}\text { Amount contributed } \\
\text { (dollars) }\end{array}$ & $\begin{array}{c}56.1 \\
(5.86)\end{array}$ & $\begin{array}{l}41.5 \\
(5.61)\end{array}$ & $\begin{array}{l}13.6 \\
(0.89)\end{array}$ & $\begin{array}{c}14.7 \\
(8.11)\end{array}$ & $\begin{array}{c}27.9 \\
(3.20)\end{array}$ & $\begin{array}{c}81.8 \\
(4.59)\end{array}$ & $\begin{array}{c}14.1 \\
(1.24)\end{array}$ & $\begin{array}{l}67.7 \\
(3.74)\end{array}$ & $\begin{array}{c}73.3 \\
(8.01)\end{array}$ & $\begin{array}{c}18.8 \\
(1.62)\end{array}$ & $\begin{array}{l}54.5 \\
(5.41)\end{array}$ \\
\hline $\begin{array}{l}\text { Amount contributed } \\
\text { (conditional on } \\
\text { contribution) }\end{array}$ & $\begin{array}{l}558 \\
(40)\end{array}$ & $\begin{array}{l}672 \\
(63)\end{array}$ & $\begin{array}{l}439 \\
(19)\end{array}$ & $\begin{array}{l}-114 \\
(71)\end{array}$ & $\begin{array}{l}233 \\
(49)\end{array}$ & $\begin{array}{l}913 \\
(35)\end{array}$ & $\begin{array}{l}555 \\
(37)\end{array}$ & $\begin{array}{l}358 \\
(55)\end{array}$ & $\begin{array}{l}823 \\
(62)\end{array}$ & $\begin{array}{l}677 \\
(47)\end{array}$ & $\begin{array}{l}146 \\
(84)\end{array}$ \\
\hline $\begin{array}{l}\text { Amount contributed } \\
\text { (inclusive of match) }\end{array}$ & $\begin{array}{l}82.5 \\
(8.20)\end{array}$ & $\begin{array}{l}41.5 \\
(5.61)\end{array}$ & $\begin{array}{c}13.6 \\
(0.89)\end{array}$ & $\begin{array}{l}41.0 \\
(9.90)\end{array}$ & $\begin{array}{c}27.9 \\
(3.20)\end{array}$ & $\begin{array}{l}117.2 \\
(6.25)\end{array}$ & $\begin{array}{c}14.1 \\
(1.24)\end{array}$ & $\begin{array}{l}103.1 \\
(4.85)\end{array}$ & $\begin{array}{c}105.1 \\
(10.94)\end{array}$ & $\begin{array}{c}18.8 \\
(1.62)\end{array}$ & $\begin{array}{l}86.3 \\
(6.01)\end{array}$ \\
\hline Observations & 1,561 & 1,588 & 12,703 & & & 6,063 & 11,515 & & 1,617 & 13,261 & \\
\hline
\end{tabular}

Notes: This table presents the X-IRA outcomes across treated and control groups for the three groups of offices. Standard errors in parentheses below the coefficients.

\section{REFERENCES}

Bertrand, Marianne, Dean Karlin, Sendhil Mullainathan, Eldar Shafir, and Jonathan Zinman. 2005. "What's Psychology Worth? A Field Experiment in the Consumer Credit Market." National Bureau of Economic Research Working Paper 11892.

Choi, James J., David Laibson, and Brigitte C. Madrian. 2004. "Plan Design and 401(K) Savings Outcomes." National Tax Journal, 57(2): 275-98.

Choi, James J., David Laibson, Brigitte C. Madrian, and Andrew Metrick. 2002. "Defined Contribution Pensions: Plan Rules, Participant Choices, and the Path of Least Resistance." Tax Policy and the Economy, 16: 67-113.

Davis, Douglas D. 2006. "Rebate Subsidies, Matching Subsidies and Isolation Effects.” Judgment and Decision Making, 1(1): 13-22.

Davis, Douglas D., and Edward L. Millner. 2005. "Rebates, Matches, and Consumer Behavior." Southern Economic Journal, 72(2): 410-21.

Davis, Douglas D., and Edward L. Millner. 2006. "On Rebate Subsidies, Matching Subsidies and the Methodology of Experiments." Virginia Commonwealth University Department of Economics Working Paper 0604.

Davis, Douglas D., Edward L. Millner, and Robert J. Reilly. 2005. "Subsidy Schemes and Charitable Contributions: A Closer Look.” Experimental Economics, 8(2): 85-106.

Duflo, Esther, and Emmanuel Saez. 2002. "Participation and Investment Decisions in a Retirement Plan: The Influence of Colleagues' Choices.” Journal of Public Economics, 85(1): 121-48.

Duflo, Esther, William Gale, Jeffrey Liebman, Peter Orszag, and Emmanuel Saez. 2006. "Saving Incentives for Low- and Middle-Income Families: Evidence from a Field Experiment with H\&R Block." Quarterly Journal of Economics, 121(4): 1311-46.

Eckel, Catherine C., and Philip J. Grossman. 2003. "Rebates Versus Matching: Does How We Subsidize Charitable Contributions Matter?" Journal of Public Economics, 87(3-4): 681-701.

Eckel, Catherine C., and Philip J. Grossman. 2005. "Subsidizing Charitable Contributions: A Field Test Comparing Matching and Rebate Subsidies.” Unpublished. 
Eckel, Catherine C., and Philip J. Grossman. 2006a. "Do Donors Care About Subsidy Type? An Experimental Study." In Research in Experimental Economics. Vol. 11, ed. R. Marc Isaac and Douglas D. Davis, 163-82. New York: Elsevier.

-Eckel, Catherine C., and Philip J. Grossman. 2006b. "Subsidizing Charitable Giving with Rebates or Matching: Further Laboratory Evidence.” Southern Economic Journal, 72(4): 794-807.

Eckel, Catherine C., and Philip J. Grossman. 2006c. "Subsidizing Charitable Contributions: Evidence from a Non-Secular Charity." Unpublished.

Engelhardt, Gary V., and Anil Kumar. 2004. "Employer Matching and 401(k) Saving: Evidence from the Health and Retirement Study." Center for Retirement Research Working Paper 2004-18.

Even, William E., and David A. MacPherson. 2005. "The Effects of Employer Matching in 401(K) Plans." Industrial Relations, 44(3): 525-49.

-Huberman, Gur, Sheena S. Iyengar, and Wei Jiang. 2007. "Defined Contribution Pension Plans: Determinants of Participation and Contributions Rates." Journal of Financial Services Research, 31(1): $1-32$.

Kahneman, Daniel, and Amos Tversky. 1979. "Prospect Theory: An Analysis of Decision under Risk." Econometrica, 47(2): 263-91.

-Karlan, Dean, and John A. List. 2007. "Does Price Matter in Charitable Giving? Evidence from a Large-Scale Natural Field Experiment.” American Economic Review, 97(5): 1774-93.

-Katz, Lawrence F., Jeffrey R. Kling, and Jeffrey B. Liebman. 2001. "Moving to Opportunity in Boston: Early Results of a Randomized Mobility Experiment." Quarterly Journal of Economics, 116(2): 607-54.

- Madrian, Brigitte C., and Dennis F. Shea. 2001. "The Power of Suggestion: Inertia in 401(K) Participation and Savings Behavior." Quarterly Journal of Economics, 116(4): 1149-87.

-Meier, Stephan. 2007. "Do Subsidies Increase Charitable Giving in the Long Run? Matching Donations in a Field Experiment." Journal of the European Economic Association, 5(6): 1203-22.

Saez, Emmanuel. 2007. "Details Matter: The Impact of Presentation and Information on the Take-up of Financial Incentives for Retirement Saving." CEPR Discussion Paper 6386.

Thaler, Richard H., and Shlomo Benartzi. 2004. "Save More Tomorrow: Using Behavioral Economics to Increase Employee Saving." Journal of Political Economy, 112(1): S164-87. 